\title{
An operational biogeochemical model of the North-East Atlantic: model description and skill assessment
}

Tomasz Dabrowski*, Kieran Lyons, Alan Berry, Caroline Cusack, Glenn D. Nolan

Marine Institute, Rinville, Oranmore, Ireland

*Corresponding author: tomasz.dabrowski@ marine.ie, phone: +35391387367 


\begin{abstract}
This paper presents a high resolution operational biogeochemical model of the North-East Atlantic that encompasses part of the continental shelf and adjacent deep sea and includes all of Ireland's territorial waters. The setup of the model is described, followed by its skill assessment in reproducing chlorophyll and nitrate spatio-temporal variability. Part of the model skill assessment concerns the evaluation of its usefulness in a decision-making process and is based on the application of a binary discrimination analysis. The model is one-way nested within a $1 / 12^{\circ}$ Mercator Ocean PSY2V4R2 operational model that provides physical forcing at the lateral open boundaries. Nitrate fields are also proscribed at the open boundaries; World Ocean Atlas 2009 monthly climatologies are used in the upper $500 \mathrm{~m}$ and at greater depths a formula that relates nitrate concentration to temperature and latitude is applied in the model. The model represents intra-annual variability of surface chlorophyll and nitrate concentrations at monthly time scales across key oceanographic regions reasonably well; deficiencies are identified in some regions along with possible causes. The model can reproduce important characteristic bio-physicochemical features e.g. the frontal dynamics and upwelling off southwest Ireland and the properties of different water masses in the Rockall Trough. The model is deemed suitable for operational purposes, with a high probability to make correct positive and negative decisions. Operational since 2011, the output is publicly available via a dedicated THREDDS server.
\end{abstract}

Keywords: Mathematical models; Ecosystems; Biogeochemistry; Oceanography; North-East Atlantic; ROMS 


\section{Introduction}

Recent years saw an increase in nowcast and forecast ocean models developed for operational oceanography in response to the needs of a wide range of the end-users in the marine community. Endusers include scientists, marine and coastal environment managers, navigation safety, fisheries and aquaculture industries and other stakeholders from both public and private sector (e.g. oil industry, marine renewables). In the last decade, a major EU initiative, involving 72 institutions, the European Coastal Sea Operational Observing and Forecasting System Project (ECOOP), agreed to build capacity in the area of operational observing and forecasting systems for the oceans. Other EU funded projects, such as the Collaborative European Atlantic Water Quality Forecasting System (EASYCO), presented here, share a similar goal.

A plethora of ocean numerical models were developed within the last c. 40 years, to serve as tools to address particular research requirements. Many of these models can be successfully adopted as operational models; however, their distinct feature is that they generally serve broader interests. Also, these models are expected to produce sensible results across the entire model domain for all targeted state variables with reasonable computational efficiency. It has some important implications for the configuration of these models, especially at the early stages of their life cycle, as end-users needs may not be fully established.

Whilst operational models that forecast the physical state of the oceans exist for European oceans (e.g. Holt et al., 2003; Elliott et al., 2007; Siddorn et al., 2007; Korotaev et al., 2011; Kordzadze and Demetrashvili, 2011; Stanev et al., 2011; Zhuang et al., 2011; Mateus et al., 2012), few models routinely produce forecasts of the biogeochemical fields (e.g. Siddorn et al., 2007; Mateus et al., 2012; Wan et al., 2012). A requirement for explicit operational modelling of the combined physical, chemical and biological systems stems from a growing realisation that the biogeochemical state of our seas cannot be inferred from their physical properties alone (e.g. Blackford et al., 2004). Moreover, as reviewed by Doney et al. (2004) a substantial fraction of the differences in the predicted biogeochemical fields between models represent the propagation of known errors in the model physics. The errors usually result from unresolved, poorly resolved or neglected physical processes. In most cases, the model resolution can be refined to eliminate or reduce the errors. Today, real or near-real time data for model forcing and accurate forecasts of the atmosphere and ocean states allow important physical features to be resolved in models with adequate grid spacing. Whilst in meteorology, the forecasts have been produced routinely for decades, large scale ocean state forecasts required for downscaling to regional and local levels are only a recent development. The provision of modelling services for operational oceanography, whereby the solutions are downscaled from global to local levels, is one of the goals of the European Earth Observation Programme, Copernicus (formerly Global Monitoring for Environment and Security). Within this context the model presented in this study is part of an intermediate level service, meaning 
that it depends on upstream large scale data and products required for the model set-up, forcing and validation, whereas the output from the model provides downstream services to local users.

Marine ecosystem models have been developed in recent years to understand, quantify and predict key biogeochemical processes in the oceans. The models vary in complexity from simple four-compartment Nitrate, Phytoplankton, Zooplankton, Detritus (NPZD) pelagic models (e.g. Oschlies et al., 2000) to more complex multi-nutrient and multi-functional group models (e.g. Lima and Doney, 2004; Vichi et al., 2007; Mateus, 2012) and benthic-pelagic models with over 40 state variables such as ERSEM, one of the most complex lower trophic-level marine ecosystem models in use (Baretta et al., 1995). However, as reported by Allen et al. (2007) following the previous review of the performance of 153 biological models incorporating plankton, the ambitious efforts to increase the level of biological detail and spatial complexity has not lead to a systematic improvement in model performance and the overall skill of the models remains poor. Only $47 \%$ of models assessed had been validated and only $30 \%$ of models had determined some measure of goodness of fit. Compared to physical oceanography, field data for chemical and biological oceanography is scarce; this remains an obstacle to improve biogeochemical model skill (Ward et al., 2010).

This paper describes a North-East Atlantic operational biogeochemical model and assesses its skill with a focus on chlorophyll (Chla; a proxy for phytoplankton biomass) and nitrate $\left(\mathrm{NO}_{3}\right)$ fields. Since the model is part of the operational suite maintained by the Irish Marine Institute it will likely influence decisionmakers and so part of the model skill assessment evaluates its usefulness in the decision-making process. The evaluation also investigates the model's capabilities to reproduce some known bio-physical features in Irish waters.

\section{Methods}

The numerical model used in this study is the Regional Ocean Modelling System (ROMS), a freesurface, hydrostatic, primitive equation ocean model described in detail by Shchepetkin and McWilliams (2005). To date, ROMS has demonstrated substantial skill in forecasting (Haidvogel et al., 2008) and is used in successful operational systems (e.g. Chao et al., 2009; Chiggiato and Oddo, 2008).

Biogeochemical models of varying complexity have been dynamically coupled to ROMS. In this study, a simple nitrogen-based NPZD model developed originally for the US east coast and described in Fennel et al. (2006) was used. This section describes the configurations of both the hydrodynamic and biogeochemical models, and the model skill assessment methods.

\subsection{Hydrodynamic model set-up}

This section provides a very brief description of the hydrodynamic model set-up; more details are presented in a separate publication.

The model domain covers a significant portion of the North-West European continental shelf with a horizontal and vertical resolution of $\sim 4 \mathrm{~km}$ and 40 sigma levels, respectively (Fig. 1). It is one-way 
nested within the high resolution (1/12 $)$ Mercator Ocean (http://www.mercator-ocean.fr) PSY2V4R2 operational model of the North Atlantic whereby daily values for potential temperature, sea surface height and velocity are linearly interpolated at the open ocean boundaries. Tidal forcing is proscribed at the model boundaries by applying elevations and barotropic velocities for ten major tidal constituents, obtained from the TPXO7.2 global inverse barotropic tide model (Egbert and Erofeeva, 2002). The model bathymetry utilizes data from different sources: GEBCO_08 grid (http://www.gebco.net), Brown et al. (1999), the Irish National Seabed Survey (INSS), the Integrated Mapping for the Sustainable Development of Ireland's Marine Resource (INFOMAR) along with an extensive single-beam archive maintained by the Marine Institute.

Recursive MPDATA is used for advection of tracers (Margolin and Smolarkiewicz, 1999). Surface forcing uses the half-degree 6-hourly forecast from the Global Forecasting System (GFS) freely provided by the U.S. National Center for Environmental Prediction (NCEP/NOAA). The shortwave heating of the water column is modelled using the coefficients for the Jerlov 1B water type (Jerlov, 1976). Thirty-eight rivers are included: major rivers of Ireland, west Britain and west France and some minor Irish rivers. Discharge rates are daily average values calculated from multiple years.

\subsection{Biogeochemical model set-up}

The NPZD model is a pelagic nitrogen-based model and comprises seven state variables. The emphasis of the model architecture is not to differentiate various phytoplankton groups as primary producers or various zooplankton grazer groups. The reader is referred to Fennel et al. (2006) for a schematic representation of the nitrogen cycle in the model.

Phytoplankton $(P)$ growth in the model is a function of light (P-I relationship), temperature (Eppley relationship) and $\mathrm{NO}_{3}$ and ammonium $\left(\mathrm{NH}_{4}\right)$ concentrations (Michaelis-Menten relationship). The relationship between Chla and $P$ is nonlinear, and the effects of photoacclimation are included based on the model of Geider et al. (1996; 1997). Grazing is represented by a Holling type S shaped curve to limit grazing at high phytoplankton concentrations. The mortality of phytoplankton is simply proportional to concentration and for zooplankton $(Z)$ it is proportional to the concentration squared. The deceased plankton (as well as unassimilated food) goes into the small detritus $(S D)$ pool and these aggregate into large detritus $(L D)$ at a fixed rate. Both fractions have their own sinking velocities. The model instantaneously remineralises, nitrifies and de-nitrifies a portion of the particulate matter arriving at the sediment-sea interface. More details on model formulations can be found in Fennel et al. (2006). To improve model performance in the studied region, some of the parameter values given in Fennel et al. (2006) were modified (Table 1).

Initial and boundary conditions for nitrate are derived from World Ocean Atlas 2009 (WOA09) (Garcia et al., 2010) and were modified based on analysis of collated regional data. Analysis revealed a relationship between the temperature, latitude and nitrate concentration in deep waters (depth $>500 \mathrm{~m}$ ). The dataset analyzed included measurements collected on several marine surveys: three RV Celtic 
Explorer surveys in February 2009 (CE0903), February 2010 (CE10002) and January 2011 (CE11011), one $R V$ Thalassa survey in February 2008 (TH08), and a WOCE-AR24 survey completed in November/December 1996 (CDIAC database; https://cdiac.ornl.gov/oceans/). A multiple linear regression tool available in R package (http://www.r-project.org/) was used with the following best-fit equation:

$$
N O_{3}=-0.102 \cdot L a t+37.078 \cdot T-2.260 \cdot T^{2}+0.046 \cdot T^{3}-198.465 \cdot \log (T)+27.683
$$

Where Lat is latitude in degrees (north-positive) and $T$ is water temperature in ${ }^{\circ} \mathrm{C}$. The above equation is based on 529 observations, Lat ranged from 48.5 to $55.9^{\circ} \mathrm{N}, \mathrm{T}$ from 2.4 to $11.1^{\circ} \mathrm{C}$, and $\mathrm{NO}_{3}$ from 9.3 to $27 \mathrm{mmol} \mathrm{N} \mathrm{m}^{-3}$. The adjusted $R^{2}$ value is 0.82 and the residual standard error is 1.13 .

The above relationship was applied to obtain the deep water $\mathrm{NO}_{3}$ initial fields and boundary conditions. In the upper $500 \mathrm{~m}$, WOA09 fields were applied. The initial values of other biological state variables were set as homogeneous low values; $0.1 \mathrm{mmol} \mathrm{N} \mathrm{m}^{-3}$. These low values were also used at the open ocean boundary conditions. River input values of $\mathrm{NH}_{4}, \mathrm{NO}_{3}$ and $\mathrm{SD}$ are prescribed for all Irish, UK and French rivers; data was obtained from the Irish EPA, CEFAS in the UK and Ifremer in France. The inputs were further tuned to equal the total annual loadings in each OSPAR region (OSPAR, 2010). The annual loadings were subsequently scaled by the total freshwater flux for each river to obtain daily inputs.

The biogeochemical model was initialized on $1^{\text {st }}$ of March 2009 for c. 2 years spin-up run. The start date corresponds to the time of maximum mixed layer depth (MLD) throughout most of the modelled area, a time of low phytoplankton activity is also expected. The MLD, based on the surface-to-depth temperature difference of $0.2{ }^{\circ} \mathrm{C}$ criterion is at its maximum in early March in the area defined by the 50$60^{\circ} \mathrm{N}$ latitude and 8-24 W longitude. Maximum nitrate concentrations are expected at this time of year with minimum phytoplankton activity controlled by low temperatures and light availability in the region. Figure 2 presents the annual pattern of MLD in the region, its spatial distribution on $1^{\text {st }}$ March 2009, which was obtained from the Mercator PSY2V4R2 model and monthly surface nitrate climatology from WOA09 averaged over the same area.

The operational set-up comprises a 3-day forecast and a 7-day hindcast cycle. A rolling month of data hindcast/forecast model output is published to the Marine Institute THREDDS server (http://milas.marine.ie/thredds/catalog.html).

\subsection{Observational data sets for model validation}

Remotely sensed chlorophyll fields were retrieved from NASA's MODIS satellite at $4 \mathrm{~km}$ resolution. Due to cloudiness in the study region, the temporal scale of a month was used to ensure adequate data coverage; data was obtained from Giovanni online data system developed and maintained by the NASA Goddard Earth Sciences Data and Information Services Centre (Acker and Leptoukh, 2007). Monthlyaveraged nitrate fields were compared against the WOA09 monthly climatologies. Finally, the model 
capability to represent some of the known bio-physical features in Irish waters was assessed; these are introduced and discussed of section 3.

\subsection{Model skill assessment}

The model skill assessment was carried out for the year 2011 following c. 2 year spin-up simulation.

Chlorophyll is the most commonly used parameter in the validation of the biogeochemical models due to wide availability of data, both in-situ and remotely sensed, and is a focus of this assessment. Some validation for nitrate fields is also presented. At this stage of model development, the aim is to assess the models broad capability at reproducing main observed seasonal features for phytoplankton and nitrates. For the purpose of this analysis the model domain was divided into subareas that represent key oceanographic regions (Fig. 1). The initial assessment of the model was qualitative. Monthly-averaged surface chlorophyll and nitrate were compared against MODIS and WOA09, respectively, for each region. We then visually compared fluctuations of seasonally averaged surface chlorophyll in the model and MODIS. Spring was defined as March-May, summer as June-August and autumn as SeptemberNovember. Winter months were excluded from this comparison due to low phytoplankton activity and inadequate MODIS coverage in the study area in December and January due to high latitudes. A quantitative validation was carried out to assess the models usefulness as an operational tool in the decision-making process. The following statistical measures were used: the Model Efficiency (ME) (Nash and Sutcliffe, 1970), the Cost Function (CF) (OSPAR et al., 1998), the Percentage of Bias (PB) (Allen et al., 2007) and the Adjusted Relative Mean Absolute Error (ARMAE) (Sutherland et al., 2004). These statistics deliver complementary information about the model performance and are defined as follows:

$$
\begin{aligned}
& M E=1-\frac{\Sigma(D-M)^{2}}{\Sigma(D-\bar{D})^{2}} \\
& C F=\frac{\Sigma|M-D|}{n \sigma_{D}} \\
& P B=\left|\frac{\Sigma(D-M)}{\Sigma D} \cdot 100\right| \\
& \text { ARMAE }=\frac{\langle M-D \mid-O E\rangle}{\langle|D|\rangle}
\end{aligned}
$$

where observations, $D(i, j, t)$, and model, $M(i, j, t)$, fields are defined in a $I x J$ spatial grid and in $T m$ points in time, where each time $t$ represents a monthly mean $(\mathrm{t}=\{1,2, \ldots, 12\})$ for each analyzed subregion. $\bar{D}$ in the above equations represents the total space-time mean of observations in each subregion (i.e. $D \overline{i, j, t}), n$ is the number of observations, $\sigma_{D}$ is the standard deviation of all observations and $O E$ is the observational error. The angular brackets in equation (5) denote the average, and negative values in the numerator of this equation are set to zero before averaging. Based on the work of Moore et al. (2009) and 
following Siddorn et al. (2007) we used a conservative estimate of the observational error at 50\% (absolute relative error). The above statistics were calculated for the months of February-October for all regions, except the Celtic Sea and the Bay of Biscay, since at high latitudes MODIS data are not available in winter months. In the Celtic Sea, the time period used was February-November, and in the Bay of Biscay January-November. ME is cited as a performance indicator where $>0.65=$ excellent, 0.5 $0.65=$ very good, $0.2-0.5=$ good, and $<0.2=$ poor/bad (Maréchal, 2004). CF is a measure of the "goodness of fit" of the model and data: $<1=$ excellent/very good, 1-2 = good, 2-3 = reasonable and $>3$ $=$ poor/bad (Radach and Moll, 2006). PB is also cited as a performance indicator: $<10=$ excellent, 10-20 $=$ very good, $20-40=$ good, $>40=$ poor/bad (Maréchal, 2004). ARMAE classifies the model as follows: $<0.2=$ excellent/very good, $0.2-0.4=$ good, $0.4-0.7=$ reasonable, $0.7-1.0=$ poor and $>1.0=$ bad (Sutherland et al., 2004).

A Binary Discriminator Test employing the Receiver Operator Characteristic (ROC) described in Stow et al. (2009) was carried out to evaluate the model predictive power. This category of tests is used to determine whether the fit of the model and observations is better or worse than we would obtain if the model was replaced by a random number generator and how well it quantifies skill as a function of threshold using a binary discriminator, e.g. what is the probability that the model predicts a phytoplankton bloom defined as chlorophyll concentration above a defined threshold? The test is based on a simple yes/no decision and has four possible outcomes: correctly positive $(\mathrm{CP})$, correctly negative (CN), incorrectly positive (IP) and incorrectly negative (IN). An observational error of $50 \%$ for MODIS data was assumed here, and for a given threshold value, $C h l a_{M}$, the values of CP, CN, IP and IN were determined as explained in Figure 3. The test was carried out for pairs of monthly-averaged model/observations at each grid cell $(i, j)$ for each subregion separately. The outcome of the test was used to calculate the correct negative fraction $(\mathrm{CNF})$ and the correct positive fraction (CPF) from:

$$
\begin{aligned}
& C N F=\frac{C N}{C N+I P} \\
& C P F=\frac{C P}{C P+I N}
\end{aligned}
$$

The value of CPF is the probability that the event was classified correctly as above the $C h l a_{M}$, whereas the value of (1-CNF) is the probability that the event was classified correctly as below Chla $a_{M}$. The perfect model is when $\mathrm{CPF}=1$ and $\mathrm{CNF}=1$. In this study, thirty thresholds of Chla concentration were used varying from 0.1 to $3.0 \mathrm{mg} \mathrm{m}^{-3}$ with an increment of 0.1 . Subsequently, the probabilities of making the correct positive or negative decisions at each threshold were calculated from:

$$
\begin{aligned}
& P P V=\frac{C P}{C P+I P} \\
& N P V=\frac{C N}{C N+I N}
\end{aligned}
$$

where PPV is the positive predictive value and NPV is the negative predictive value. Their values are in the range between 0 and 1 , and high values indicate that the decision can be trusted, whereas low values 
indicate that the decision should be treated with caution. Stow et al., (2009) provide a more detailed description of the test along with the examples.

Following the above quantitative skill assessment, the model was examined for its capabilities to reproduce certain bio-physical features in Irish waters; these are introduced in section 3.

\section{Results and discussion}

\subsection{Chlorophyll}

\subsubsection{Spatial maps and monthly time series}

Spring, summer and autumn surface chlorophyll concentrations predicted by the model and collected by MODIS are presented in Figure 4. Overall, the model compares reasonably well with remotely sensed data. Particularly good agreement is observed in spring across all regions. In summer, the model overestimates chlorophyll concentrations in offshore waters, north of c. $50^{\circ} \mathrm{N}$, characterized by high winter nitrate concentrations (typically twice as high as in the Celtic Sea). In autumn, the model has a tendency to overpredict surface chlorophyll concentrations in offshore waters, most notably in the deep waters of the Bay of Biscay, and underestimate concentrations in the Irish Sea. Regions can be identified where the model performs visibly well and also regions where the performance is rather poor. As regards the former, these are most waters adjacent to the Irish coast (except parts of the Irish Sea) and the Celtic Sea where the spring bloom, the decrease of the concentrations in the summer, and the second autumn bloom of lower magnitude are manifested. In spring and summer elevated chlorophyll levels along the shelf edge from the coast of France towards Irish waters are evident in both MODIS and the model. The areas of worst model performance include the Irish Sea - where underprediction occurs particularly in summer and autumn. This is most likely caused by intra-annual variability of nutrient load from rivers not properly reflected in the model, although MODIS can overestimate chlorophyll in coastal regions. The model tends to overpredict surface concentrations in deep waters north of c. $50^{\circ} \mathrm{N}$ in all seasons and in deep waters of the Bay of Biscay in summer and autumn. Underprediction in the English Channel can be attributed to low-chlorophyll level boundary conditions.

Figure 5 presents the time series of modelled and observed monthly chlorophyll in the analyzed regions. A strong spring bloom, prominent peak in all graphs, is evident in both the model and satellite data. Overall, the model can discriminate the increase and decrease of bloom events. The time lag, delayed occurrence of the spring bloom, from south to north is recorded by both MODIS and the model (e.g. April in the Bay of Biscay; June in Rockall Bank area). Several regions can be identified with good quantitative model performance based on visual assessment. These are the Bay of Biscay (Fig. 5a), the Celtic Sea (Fig. 5b), the Irish Shelf (Fig. 5c) and Malin Shelf (Fig. 5d). In the remaining regions, except the Irish Sea, the model visibly overestimates chlorophyll, although the overall annual pattern seems to be properly resolved (e.g. see Porcupine Seabight in Fig. 5f). 


\subsubsection{Quantitative model skill assessment}

The computed statistics defined by equations (2)-(5) for the modelled vs. observed surface chlorophyll are summarized in Table 2. The statistical measures used in this study return different results as to the performance level of the model compared to MODIS. The model scores highest based on the values of ME with an excellent skill level for all examined subregions. ME given by eq. (2) is a measure of the ratio of the model error to the data variability, with the squaring operation rewarding a good fit and punishing a poor fit. Since the average of the observations, $\bar{D}$, is taken as the total time-space average, it indicates the efficiency of the modelling effort in delivering predictions, that are of more value than the annual average of chlorophyll in a given region. As far as the assessment based on CF is concerned, the model is assessed as excellent/very good in the Bay of Biscay and the Irish shelf seas, good over the Rockall and Porcupine Banks and all offshore waters, and reasonable in the Rockall Trough and Porcupine Bight. CF given by eq. (3) is the ratio of the mean absolute error (MAE) to the standard deviation $\left(\sigma_{D}\right)$ of the observations, and the score excellent/very good is when MAE is within one $\sigma_{D}$. The value of $\mathrm{PB}$, in turn, represents the bias normalized by the observations rather than standard deviation. The model scores excellent and very good in the Celtic Sea, Irish Shelf and Malin Shelf, good in the Bay of Biscay, and poor or bad in the remaining regions (Table 2). The assessment based on ARMAE is more rigorous, as a relative mean absolute error is used for its calculation rather than the mean bias as in the case of PB. The influence of the observational error is reduced though, therefore, ARMAE represents the relative error over and above the estimated error in the observations. The model is classified as good in the Celtic Sea and the Malin Shelf, reasonable in the Bay of Biscay, the Irish Shelf and the Irish Sea, and poor/bad in the remaining regions.

The results from the application of the binary discrimination analysis to assess the model's predictive power are presented in Figure 6. Although we applied this test to all analyzed subregions, the results are only presented for the regions bordering the coasts, as these are the regions the model is most likely to influence decisions (e.g. in relation to the phytoplankton sampling). The Irish Sea is excluded from the considerations since the model underestimates chlorophyll here relative to MODIS. The models predictive power is greater than a random predictor in all four regions, where a random outcome is represented by the line $\mathrm{CPF}=1-\mathrm{CNF}$. For all thresholds $C h l a_{M}$ the model is significantly above the random line. The concentration of points for certain thresholds are close to the perfect model (i.e. $\mathrm{CPF}=$ 1 and $\mathrm{CNF}=1$ ). The Malin Shelf region has the greatest number of points in the vicinity of a perfect skill, which confirms the qualitative assessment. The large number of points in Figure 6a with high (1$\mathrm{CNF}$ ) values is the result of the model overestimating Chla in the Bay of Biscay in the summer. Points close to $\mathrm{CPF}=0$ and $1-\mathrm{CNF}=0$, in turn, represent the extreme of the decision making process, where almost every trial is deemed negative (either correctly or incorrectly). This outcome of the test is to be expected for high values of Chla . The probabilities of making a correct decision at a given Chla concentration are shown on the right panel of Figure 6. The NPV values are high (i.e. $70 \%$ or more) in all regions when Chla $_{M}$ is above c. $1 \mathrm{mg} \mathrm{m}^{-3}$. In the case of the Bay of Biscay and the Celtic Sea (Fig. 
$6 \mathrm{~b}$ and $6 \mathrm{~d}$, respectively), this probability exceeds $90 \%$ for $C h l a_{M}>\mathrm{c} .1 \mathrm{mg} \mathrm{m}^{-3}$. The PPV values fluctuate, at different $C h l a_{M}$ levels. Low PPV values concurrent with high NPV values are expected for high $C h l a_{M}$, and such results will be obtained even in the model that overpredicts concentrations in a small area. For more practical evaluation of the model's ability to discriminate both positive and negative events, we defined a phytoplankton bloom in each region as chlorophyll concentration twice its annual average calculated from the monthly MODIS dataset. These $C h l a_{M}$ are presented in Figure 6 along with the corresponding PPV and NPV values. As can be seen, the NPV values are well above $90 \%$ in all regions, whereas the PPV values are above $80 \%$ in the Bay of Biscay, the Celtic Sea and the Malin Shelf. On the Irish Shelf the PPV is somewhat lower at c. $60 \%$. Considering that this binary discriminator test was carried out on a cell by cell basis, the obtained results are good.

\subsection{Nitrates}

Similarly to the analysis for surface chlorophyll, the monthly-averaged time series of modelled surface nitrates in each region were compared with those obtained from WOA09; the results are presented in Figure 7. In some regions, namely the Celtic Sea and the Irish Sea, the model tends to underpredict surface $\mathrm{NO}_{3}$, but, the overall annual pattern is reflected well with the timing of most intensified uptake, summer depletion and autumn/winter regeneration and mixing represented. In other regions the model appears to be both qualitatively and quantitatively good. High winter $\mathrm{NO}_{3}$ concentrations found at high latitudes (e.g. Rockall Bank and Trough) and lower $\mathrm{NO}_{3}$ concentrations at low latitudes (e.g. the Bay of Biscay) are represented in the model. Summer nitrate levels are reflected in the model. In some regions almost complete depletion takes place (e.g. the Bay of Biscay), elsewhere, summer levels are $\sim 1.5 \mathrm{mmol}$ $\mathrm{N} \mathrm{m}^{-3}$ in both the model and WOA09 data (e.g. the Celtic Sea). Winter nitrate measurements taken in January 2011 to the west of Ireland, both on the shelf and the deep ocean at multiple depths, were compared with the modelled $\mathrm{NO}_{3}$. A total of 192 observations were compared; regression plot and transect locations are presented in Figure 8. A good correlation is returned by the linear regression model, with $\mathrm{R}^{2}=0.82$ with the intercept, and $\mathrm{R}^{2}=0.79$ when intercept is set to zero. In the latter case the value of the slope is 0.94 indicating that the model slightly underestimates the observations.

\subsection{Characteristic bio-physico-chemical features in Irish waters}

\subsubsection{Phytoplankton blooms off southwestern Ireland}

Extensive studies have been carried out on the physical, chemical and biological characteristics of shelf waters off west and southwestern Ireland associated with the development of the Irish Shelf Front (ISF) (Raine and McMahon, 1998; McMahon et al, 1995). The ISF, typically defined by 35.3 isohaline, separates fresh Irish coastal waters from the oceanic Eastern North Atlantic Water (ENAW) at c. $11^{\circ} \mathrm{W}$, and is primarily controlled by salinity with vertical isohalines in winter and " $\mathrm{S}$ " shaped isohalines in summer (McMahon et al., 1995). Thermal fronts are also present in the region and intermittent upwelling events occur in summer. Dense subsurface phytoplankton blooms have been observed in the vicinity of 
fronts and elevated biological productivity is associated with upwelled colder patches (Raine et al., 1990). The Irish Coastal Current (ICC) develops in the Celtic Sea and Irish Shelf with speeds in the range of 6-20 $\mathrm{cm} \mathrm{s}^{-1}$ (Brown et al., 2003; Fernand et al., 2006). Raine and McMahon (1998) postulated that its strength off the southwest is determined by the proximity of ISF to the coast. There is growing evidence that the interaction between the ISF, ICC and wind regime drives the dynamics of harmful algal blooms (HABs) a particular burden to the aquaculture industry in the region (Raine et al., 2010). Since the presented model is currently being incorporated into the HAB warning system developed within the scope of the EU FP7 funded ASIMUTH project (www.asimuth.eu) it is important that these typical features are represented.

A manifestation of the ISF as the "S" shaped isohalines in mid-August 2011 is predicted by the model (Fig. 9b); the location of transect is shown in Figure 9a. Its surface signature in the presented plot is located at c. $10^{\circ} 45^{\prime} \mathrm{W}$, similar to field observations published by Raine and McMahon (1998) and historical Marine Institute oceanographic data (e.g. Nolan and Lyons, 2006). Despite the good manifestation of the ISF in the model, coastal salinities are slightly high. In vertical profiles the pycnocline is found at c. $25 \mathrm{~m}$ depth, this too corresponds well to field observations in summer. Vertical sections through modelled Chla and $\mathrm{NO}_{3}$ along transects IS1 and CS1 (Fig. 9a) in mid-May and mid-August 2011 are shown in Figure 9c-h. In May, Chla up to $2 \mathrm{mg} \mathrm{m}^{-3}$ is predicted in the surface mixed layer west of the ISF with slightly lower values to the east (Fig. 9c). Raine and McMahon (1998) reported highest Chla concentrations $\left(2 \mathrm{mg} \mathrm{m}^{-3}\right)$ at depth c. $20 \mathrm{~m}$ and a surface value of $1.5 \mathrm{mg} \mathrm{m}^{-3}$. In the model, the surface layer is well mixed. However, similarly to the observations, the contour line of 0.5 $\mathrm{mg} \mathrm{m}^{-3}$ lies at 50-60m depth. The distribution of $\mathrm{NO}_{3}$ (Fig. 9d) corresponds well to the observations with low concentrations in the surface mixed layer inshore of the front, and 5-6 $\mu \mathrm{M}$ offshore of the front. In the bottom mixed layer the values are much higher, and inshore of the front these are $5-8 \mu \mathrm{M}$, and offshore in excess of $9 \mu \mathrm{M}$.

In August, along transect IS1, a subsurface Chla maximum of c. $1.5 \mathrm{mg} \mathrm{m}^{-3}$ is predicted at the pycnocline inshore of the ISF (Fig. 9e), whereas offshore of ISF the Chla concentration is higher and more uniform in the surface mixed layer. Raine and McMahon (1998) report lower values offshore and up to $10 \mathrm{mg} \mathrm{m}^{-3}$ inshore of the front, in both cases concentrated at the pycnocline, a feature reflected well in the model. $\mathrm{NO}_{3}$ distribution is well predicted in August (Fig. 9f) with low concentrations in the surface mixed layer and high concentrations in the bottom mixed layer on both sides of the ISF. Only in the vicinity of the coast are nitrates depleted in the bottom layer.

In the Celtic Sea (Fig. 9g, h), predicted chlorophyll maximum up to $2.2 \mathrm{mg} \mathrm{m}^{-3}$ is closely associated with the pycnocline with surface concentrations $\leq 0.8 \mathrm{mg} \mathrm{m}^{-3}$. The pycnocline separates the nitrate-rich (6-8 $\mu \mathrm{M})$ bottom mixed waters from nitrate-depleted waters $(<0.5 \mu \mathrm{M})$ in the surface mixed layer. The depth of the pycnocline, varies between 20-30 m, the distribution and levels of modelled Chla and $\mathrm{NO}_{3}$ are thus typical of what is expected in the region at this time of year (Raine and McMahon, 1998). 
In a separate study, Roden and Raine (1994) observed further relationships between frontal dynamics and phytoplankton blooms in the west of Ireland. The authors found evidence of a spring/neap chlorophyll cycle and concluded that spring tides erode the pycnocline and mix frontal waters, and that this mechanism is the largest source of nutrients in the summer. This mechanism in combination with wind effects can cause localised upwelling in bays and near headlands advecting nutrients to the surface layer and driving localised phytoplankton blooms. In Figure 10, we demonstrate the model skill in representing the above phenomena. Figure 10a shows a relationship between the spring-neap tidal cycle and the rate of primary productivity (PP) in the surface mixed layer off the southwest between May and end of June 2011. The PP was averaged inshore of the ISF over the upper 10 sigma layers of the model between the mouth of Bantry Bay and c.100 m depth contour. In July, however, this correlation is not evident. A possible explanation is that the bottom nitrates are progressively depleted in the analyzed region inshore of the ISF as the summer season progresses (see Fig. 10d, f), and thus processes other than tidal stirring become a dominant factor driving the coastal phytoplankton dynamics. For example, the ICC may be advecting nitrate-depleted surface mixed layer waters from the Celtic Sea to the mouth of Bantry Bay. Raine et al. (1990) identified thermal fronts and upwelling events off southwest Ireland and observed higher phytoplankton biomass in upwelled colder waters than in stratified regions. The model predicts a similar event of strong upwelling between $17^{\text {th }}$ and $19^{\text {th }}$ of July 2011 and this coincided with spring tides . Figure 10b presents a section through a 3-day average of modelled vertical velocities along transect IS1 between the above dates. Strong upwelling is evident in the model between 10-50 km offshore with maximum velocities of $0.4 \mathrm{~mm} \mathrm{~s}^{-1}$ or $34 \mathrm{~m} \mathrm{~d}^{-1}$. This brings cold bottom waters $\left(\leq 11^{\circ} \mathrm{C}\right)$ to the surface and causes a drop in surface temperatures of over $1.5^{\circ} \mathrm{C}$ (see Fig. 10c, d). Modelled nitrates are transported upward during the event; surface levels increased from $<0.5 \mu \mathrm{M}$ to $4 \mu \mathrm{M}$ (see Figure $10 \mathrm{e}, \mathrm{f}$ ). Surface primary productivity was enhanced in the model as marked in Figure 10a.

\subsubsection{Physico-chemical characteristics of Rockall Trough waters}

Direct observations of physical and chemical properties of water masses in the Rockall Trough were carried out by the Marine Institute in recent years. McGrath et al. (2011) summarize the results from the February 2008, 2009 and 2010 cruises and compare to a similar WOCE (World Ocean Circulation Experiment) transect from November/December 1996. The above authors identified different water masses in the region, namely, the Eastern North Atlantic Water, Subarctic Intermediate Water, Mediterranean Water, Wyville-Thomson Overflow Water, Labrador Sea Water, Northeast Atlantic Deep Water and Antarctic Bottom Water. Figure 11a illustrates the position of the major water masses across the region extending from the Irish Shelf about $49.5^{\circ} \mathrm{N}$ across the Rockall Trough with salinities taken from the National Seabed Survey in 2010. Figure 11b shows vertical section through the modelled salinity along the same transect in mid-February 2011. The positions of different water mass types are well represented in the model. One notable difference is the extension of Mediterranean Water waters across the full width of the Porcupine Seabight, however, the salinity decreases towards the Porcupine 
Bank, as it should. More saline waters associated with the shelf edge current are also found at the continental shelf edge with highest surface salinities around the $1000 \mathrm{~m}$ depth contour. When compared with field data, surface Eastern North Atlantic Water north-west of the Porcupine Bank are more saline in the model, and the deep waters of the Porcupine Seabight are fresher than observed.

Comparison of observed and modelled $\theta-S$ (potential temperature-salinity) profiles of the southern (SROCK) and northern (NROCK) transects through the Rockall Trough are presented in Figure 11c,d and 11e,f, respectively. The model identifies the different water masses, and modelled profiles are similar to CTD casts collected on the CE10002 cruise, February 2010. The model represents deep water masses well, but tends to overestimate salinities in some surface waters. A marked difference appears in the characteristics of waters in the upper $1000 \mathrm{~m}$, with much more variability in water properties along SROCK relative to NROCK; this observation is reflected in the model.

Vertical profiles of both observed and modelled $\mathrm{NO}_{3}$ along both transects of the Rockall Trough are presented in Figure 11g. The two profiles are similar, although some differences exist, particularly below the winter mixed layer at depths of 500-1000m, here the model tends to underestimate $\mathrm{NO}_{3}$ concentrations. The surface concentrations are similar, between 7-12 $\mathrm{mmol} \mathrm{m}^{-3}$, followed by a sharp increase down to c.1000 m depth. Between 1000-2000 m depth both observed and modelled $\mathrm{NO}_{3}$ are 17$20 \mathrm{mmol} \mathrm{m}^{-3}$, the modelled $\mathrm{NO}_{3}$ is slightly underestimated, and a steady increase below $2000 \mathrm{~m}$ is observed and $\mathrm{NO}_{3}$ in excess of $22 \mathrm{mmol} \mathrm{m}^{-3}$ were measured; this structure is well represented by the model.

Table 3 summarizes the physico-chemical properties $\left(\mathrm{S}, \mathrm{T}\right.$ and $\left.\mathrm{NO}_{3}\right)$ of regional water masses after entering the Rockall Trough obtained from three Marine Institute cruises and repeated here after McGrath et al. (2011), and the model. As previously discussed, the model appears to overestimate $S$ of some of the surface water masses, however, this overestimation is only pronounced for Eastern North Atlantic Water along the SROCK transect. Subarctic Intermediate Water and Mediterranean Water are also too saline, and Subarctic Intermediate Water too warm compared with field observations. The $T$ and $S$ of the remaining water masses are properly represented by the model. Mediterranean Water are profoundly more saline, warmer and lower in nitrates than other waters at similar depths. In fact, they have the highest salinity of all listed waters, and thus they bear all typical characteristics of the Mediterranean Water. However, they appear too saline, too warm and lower in nitrates in the model when compared to the observations. A good representation of waters at depths below $1000 \mathrm{~m}$ is achieved in the model in terms of all three parameters despite the fact that these waters are tightly defined, which presents a challenging modelling task. The suitability of the relationship defining the $\mathrm{NO}_{3}$ fields proposed in this paper (eq. (1)) is confirmed. As regards the $\mathrm{NO}_{3}$ characteristics of the waters above c. $1000 \mathrm{~m}$, good representation is achieved in the model, although the Subarctic Intermediate Water, Wyville-Thomson Overflow Water and Mediterranean Water are slightly too low in nitrates relative to the observations. 


\section{Further discussion}

\subsection{Model parameterization}

Ecosystem ocean models are mathematical representations of the natural environment, in which the processes describing cycling of elements (usually $\mathrm{N}$ and/or $\mathrm{C}$, but also $\mathrm{P}$ and $\mathrm{Si}$ ) are parameterized according to our best understanding of the system. These models are usually mechanistic and are considered generic, which means they can be successfully applied to different parts of the global ocean, and may only require reparameterization of certain processes to suit local characteristics. Following extensive tests of the presented model, originally developed for the U.S. east coast continental shelf and adjacent deep ocean, significant improved performance is achieved in the studied region when some of the parameters values are changed. These include zooplankton grazing (from 0.6 to 1.3), nitrification rate (from 0.05 to 0.15 ), coagulation rate of $S D$ and $P$ (from 0.005 to 0.02 ), $S D$ remineralization rate (from 0.03 to 0.35 ), and vertical sinking velocities of $S D, L D$ and $P$ (all increased). Nitrification rate is the same as used by Maar et al. (2009) in the model of the North Sea, $S D$ remineralization rate and $L D$ sinking velocity as in the model of the western North Atlantic by Lehmann et al. (2009), $S D$ and $P$ sinking velocities as for the model of the Southern California Bight (UCLA, 2003), and the remaining parameters are all within the published ranges.

\subsection{Aspects of bio-physical coupling}

Numerous studies have shown that the mesoscale and submesoscale physical processes, apart from their influence on large-scale processes, are of critical importance on the biogeochemistry of the oceans (e.g. Lévy et al., 2012). To properly resolve these processes, the coupled bio-physical models require high resolution, which restricts their use to small ocean basins or regions to ensure computational efficiency. The high horizontal, vertical and temporal resolutions of the presented model ensure most of these processes are captured, for example, the frontal dynamics and upwelling events off southwest Ireland. Another aspect associated with the requirement for high resolution is the prescription of accurate boundary conditions. Whereas the operational products describing the physical ocean dynamics exist, such as the Mercator PSY2V4R2 solution used in this study, suitable biogeochemical oceanic fields are not yet produced operationally, and thus the climatological fields are usually used. In this study we have made an attempt to prescribe nitrate fields in deep waters expressed as a function of temperature and latitude to derive both the initial and boundary conditions, and as subsequently shown good representation of the water masses in oceanographically complex Rockall Trough was achieved. The North Atlantic Current that enters the Rockall Trough tends to elevate nutrient levels in Eastern North Atlantic Water, with nutrient concentrations increasing moving west and north in the Trough (McGrath et al., 2011). As shown in Table 3, the model reflects field data with mean $\mathrm{NO}_{3}$ higher along the northern transect than the south at least in the upper parts of Eastern North Atlantic Water, the eastwest increase in $\mathrm{NO}_{3}$ levels is also manifested in the model (not shown). McGrath et al. (2011) highlighted the importance of physical mixing in replenishing nutrients to the surface waters of the 
Trough. Since the model nitrate distribution closely matches the observations, it leads to the conclusion that this vertical mixing, including the deep winter convection is properly resolved by the model. The Rockall Trough region is a pathway for the North Atlantic waters toward the Nordic Seas, and plays an important role in the ocean-climate system. Accurate representation of the physico-chemical properties of these water masses places the model as a potentially powerful tool in climate studies of the European oceans.

\subsection{Limiting nutrients and phytoplankton functional groups}

The presented model, which performs overall to a satisfactory level with regards to both broad characteristics of the nitrogen and chlorophyll cycles in different regions covered by the model domain and also some of the more characteristic bio-physico-chemical features in Irish waters, is an example of a simple NPZD model. Some deficiencies, such as underestimation of $\mathrm{NO}_{3}$ fields and Chla in the Irish Sea will need to be improved in future releases. Also, it is known that in the North Atlantic, large diatoms often dominate the phytoplankton community at the beginning of the bloom (Sieracki et al., 1993), and subsequently constitute a major fraction of the sinking organic matter. Their growth is typically limited by silicate after the first spring bloom (Allen et al., 2005), since it is found at lower concentrations than nitrates in the North Atlantic. Recent studies also suggest iron-limitation in some parts of high-latitude North Atlantic (Nielsdóttir et al., 2009), which is in contrast to previous assumptions about nitrate and silicate (in case of diatoms) limitations in the studied part of the ocean. Post-bloom aggregation and sinking of diatoms will also impact on the predicted export rates of nutrients through the water column and thus subsequent regenerated production in the surface layers. It is therefore envisaged that the presented model will be further developed to include multi-nutrient limitation (nitrogen and silicates) and two phytoplankton compartments (diatoms and small phytoplankton). Previously, Lima and Doney (2004) carried out a 3D modelling study of the Atlantic Ocean at $0.8^{\circ}\left(\mathrm{c} .90 \mathrm{~km}\right.$ at $\left.53^{\circ} \mathrm{N}\right)$ resolution and reported improvements to the model skill following the inclusion of silica limitation. However, due to coarse resolution, the input of nutrients by mesoscale and sub-mesoscale processes suffers deficiencies in the above study, and the model presented in this paper is more likely to offer more realistic representation of mesoscale processes at least. Lehmann et al. (2009) implemented the model by Lima and Doney (2004) to the western North Atlantic at higher resolution (8 km) and observed improved agreement between the model-predicted surface chlorophyll fields with remotely sensed chlorophyll estimates compared with the model by Fennel et al. (2006) across an ecological gradient from productive to oligotrophic regions. As also shown by Bagniewski et al. (2011) in a 1-D modelling study at c. $60^{\circ} \mathrm{N}$, $20^{\circ} \mathrm{W}$ (JGOFS site), the inclusion of diatoms was crucial for capturing the termination of the spring bloom, but the fit between the model and observations improved only slightly when compared with a simpler NPZD model, similar to that presented in this paper. In the presented model we were able to contain the spring bloom at reasonable levels and prevent the total depletion of $\mathrm{NO}_{3}$ by increasing the zooplankton grazing rate, the sinking velocities of $P, S D$ and $L D$ and the coagulation rate of $P$ with $S D$, 
that would be more representative for the deceased diatoms following their die-off upon depleting silicates. Despite this effort, the spring blooms in the model are still overestimated offshore (Fig. 5), therefore it is anticipated that the proposed development of the model will improve its skill in this regard. It is worth noting that despite this overestimation, the presented model is qualitatively good, as the timings of the onset and termination of the spring blooms are represented correctly. The increased complexity of the biogeochemical models poses challenges to the process of their parameterization and thus should always be thoroughly justified. Lack of adequate continuous observations across the model domain makes the task even more difficult, particularly in relation to the vertical sinking and the zooplankton lifecycle.

\subsection{Model applications}

The operational framework in which the model operates with publicly available output implicates boundary conditions for models of the European shelf, e.g. Siddorn et al. (2007), who reported significant errors in the modelled chlorophyll in the western parts of the shelf, can benefit from the provision of biogeochemical fields at high spatial and temporal resolution. To date, the model proved valuable in delivering biogeochemical boundary conditions to a high resolution coastal model of the southwest coast of Ireland developed to study the growth of blue mussel (M. edulis) and impacts of its cultivation on ecosystem functioning (Dabrowski et al., 2013). The hydrodynamic operational model was also used to assist local aquaculture managers, for example in informing sea lice management strategies for salmon farms (Jackson et al., 2012), fisheries managers (Petitgas, 2010) and national authorities responsible for marine pollution response (Berry et al., 2012). The biogeochemical model skill assessment presented in this paper highlights the model's suitability as an operational tool (e.g. in assisting managers of ocean observation programmes in devising sampling strategies), discussed in Section 3.2.2.

\section{Conclusions and future work}

This paper presents an operational biogeochemical model of the North-East Atlantic. The model is run daily and has been operational since 2011 and the output is publicly available. Results show that, the model reproduces the intra-annual variability of surface chlorophyll and nitrate concentrations at monthly time scales across the hydrographically distinct regions. The model is deemed suitable for operational purposes, since the probabilities of making both positive and negative correct decisions at chlorophyll levels that are indicative of a phytoplankton bloom in a given region are high. The model is capable of reproducing some of the known bio-physical features in Irish waters, namely the frontal dynamics and upwelling off southwest Ireland and the physico-chemical characteristics of water masses in the Rockall Trough. 
Since the modelled region is hydrographically complex being the confluence of offshore water masses and also featuring steep topography along the shelf edge, an emphasis has been placed on good representation of the oceanographic features, which has been achieved through high model horizontal resolution and application of accurate data for the model initialization and forcing at high spatial and temporal resolutions. The relationship for prescribing the initial fields and boundary conditions for deep water nitrates was proposed in this study with the aim to achieve better representation of different water masses; this proved to work reasonably well.

The model has proved valuable in providing boundary conditions for a coastal high resolution model off the southwest Ireland. Currently it serves the basis for the development of a model that tracks the development of high biomass problematic and ichthyotoxin producing phytoplankton called Karenia mikimotoi (EU FP7 ASIMUTH project) with the aim to predict harmful outbreaks in Irish coastal waters; in this development, $K$. mikimotoi is added as a new state variable to the presented model and its lifecycle is described by its own set of equations. Improvements to the model are being considered, including an additional phytoplankton functional group (diatoms) and silicates, and more accurate representation of nutrient and freshwater inputs by rivers (near-real time data). Future developments are also envisaged to include carbon cycling (both organic and inorganic), an important component in model simulations of climate studies, oxygen dynamics and benthic processes. Data assimilation of available physical variables is currently being considered to further reduce errors in the modelled physical fields and their influence on the biogeochemical fields, followed by the biogeochemical data assimilation in the future.

\section{Acknowledgements}

This study was funded by the EU Interreg IVB Atlantic Area Programme and was part of the EASYCO (Collaborative European Atlantic Water Quality Forecasting System) project.

Remotely sensed chlorophyll was obtained from the Giovanni online data system, developed and maintained by the NASA GES DISC. We also acknowledge the MODIS mission scientists and associated NASA personnel for the production of the data used in this research effort

\section{References}

Acker, J.G., Leptoukh, G., 2007. Online Analysis Enhances Use of NASA Earth Science Data. Eos, Trans. AGU, Vol. 88, No. 2 (9 January 2007), pages 14 and 17.

Allen, J.T., Brown, L., Sanders, R., Moore, C., Mustard, A., Fielding, S., Lucas, M., Rixen, M., Savidge, G., Henson, S., Mayor, D., 2005. Diatom carbon export enhanced by silicate upwelling in the northeast Atlantic. Nature 437, 728-732.

Allen, J.I., Somerfield, P.J., Gilbert, F.J., 2007. Quantifying uncertainty in high-resolution coupled hydrodynamic-ecosystem models. Journal of Marine Systems 64, 3-14. 
Arhonditsis, G.B., Brett, M.T., 2004. Evaluation of the current state of mechanistical aquatic biogeochemical modelling. Marine Ecology Progress Series 271, 13-26.

Bagniewski, W., Fennel, K., Perry, M.J., D’Asaro, E.A., 2011. Optimizing models of the North Atlantic spring bloom using physical, chemical and bio-optical observations from a Lagrangian float.

Biogeosciences 8, 1291-1307.

Baretta, J.W., Ebenhoeh, W., Ruardij, P., 1995. The European Regional Seas Ecosystem Model, a complex marine ecosystem model. Netherlands Journal of Sea Research 33(3-4), 233-246.

Berry, A., Dabrowski, T., Lyons, K., 2012. The oil spill model OILTRANS and its application to the Celtic Sea. Marine Pollution Bulletin 64, 2489-2501.

Blackford, J.C., Allen, J.I., Gilbert, F.J., 2004. Ecosystem dynamics at six contrasting sites: a generic modelling study. Journal of Marine Systems 52, 191-215.

Brown, J., Joyce, A.E., Aldridge, J.N., Young, E.F., Fernand, L., Gurbutt, P.A., 1999. Further Identification and Acquisition of Bathymetric Data for Irish Sea Modelling. Centre for Environment, Fisheries and Aquaculture Science, Lowestoft, UK, 37 pp.

Brown, J., Carillo, L., Fernand, L., Horsburgh, K.J., Hill, A.E., Young, E.F., 2003. Observations of the physical structure and seasonal jet-like circulation of the Celtic Sea and St. George's Channel of the Irish Sea. Continental Shelf Research 23, 533-561.

Chao, Y., Li, Z., Farrara, J., McWilliams, J. C., Bellingham, J., Capet, X., Chavez, F., Choi, J.-K., Davis, R., Doyle, J., Frantaoni, D., Li, P. P., Marchesiello, P., Moline, M. A., Paduan, J., Ramp, S., 2009. Development, implementation and evaluation of a data-assimilative ocean forecasting system off the central California coast. Deep-Sea Research II: Topical Studies in Oceanography 56(3-5), 100-126.

Chiggiato, J., Oddo, P., 2008. Operational ocean models in the Adriatic Sea: a skill assessment. Ocean Science 4, 61-71.

Dabrowski, T., Lyons, K., Curé, M., Berry, A., Nolan, G., 2013. Numerical modelling of spatio-temporal variability of growth of Mytilus edulis (L.) and influence of its cultivation on ecosystem functioning. Journal of Sea Research 76, 5-21. doi:10.1016/j.seares.2012.10.012.

Doney, S.C., Lindsay, K., Caldeira, K., Campin, J.-M., Drange, H., Dutay, J.-C., Follows, M., Gao, Y., Gnanadesikan, A., Gruber, N. and others, 2004. Evaluating global ocean carbon models: The importance of realistic physics. Global Biogeochemical Cycles 18, GB3017.

Egbert, G.D., Erofeeva, S.Y., 2002. Efficient inverse modeling of barotropic ocean tides. Journal of Atmospheric and Oceanic Technology 19, 183-204.

Elliott, A., Hartnett, M., O’Riain, G., Dollard, B., 2007. The PRISM Project: Predictive Irish Sea Models. Final Report. European Union Interreg IIIA. March 2007.

Fennel, K., Wilkin, J., Levin, L., Moisan, J., O’Reilly, J., Haidvogel, D., 2006. Nitrogen cycling in the Middle Atlantic Bight: Results from a three-dimensional model and implications for the North Atlantic nitrogen budget. Global Biogeochemical Cycles 20, GB3007. doi:10.1029/2005GB002456.

Fernand, L., Nolan, G.D., Raine, R., Chambers, C.E., Dye, S.R., White, M., Brown, J., 2006. The Irish coastal current: A seasonal jet-like circulation. Continental Shelf Research 26(15), 1775-1793. 
Garcia, H. E., Locarnini, R.A., Boyer, T.P., Antonov, J.I., Zweng, M.M., Baranova, O.K., Johnson, D.R., 2010. World Ocean Atlas 2009, Volume 4: Nutrients (phosphate, nitrate, silicate). S. Levitus, Ed. NOAA Atlas NESDIS 71, U.S. Government Printing Office, Washington, D.C., 398 pp.

Geider, R.J., MacIntyre, H.L., Kana, T.M., 1996. A dynamic model of photoadaptation in phytoplankton. Limnology and Oceanography 41, 1-15.

Geider, R.J., MacIntyre, H.L., Kana, T.M., 1997. Dynamic model of phytoplankton growth and acclimation: responses of the balanced growth rate and the chlorophyll $a$ :carbon ratio to light, nutrientlimitation and temperature. Marine Ecology Progress Series 148, 187-200.

Haidvogel, D.B., Arango, H., Budgell, W.P., Cornuelle, B.D., Curchitser, E., Di Lorenzo, E., Fennel, K., Geyer, W.R., Hermann, A.J., Lanerolle, L., Levin, J., McWilliams, J.C., Miller, A.J., Moore, A.M., Powell, T.M., Shchepetkin, A.F., Sherwood, C.R., Signell, R.P., Warner, J.C., Wilkin, J., 2008. Ocean forecasting in terrain-following coordinates: Formulation and skill assessment of the Regional Ocean Modeling System, Journal of Computational Physics 227, 3595-3624.

Holt, M., Li, Z., Osborne, J., 2003. Real time forecast modeling for the NW European Shelf Seas, in: Dahlin, H., Flemming, N.C., Nittis, K., Petersson, S.E. (Eds.), Building the European Capacity in operational Oceanography. Proceedings of the Third International Conference on EuroGOOS. Elsevier Oceanography Series 69, 484-489.

Jackson, D., O'Donohoe, P., Kane, F., Kelly, S., McDermott, T., Drumm, A., Lyons, K., Nolan, G., 2012. Result of an epidemiological study of sea lice infestation in South Connemara, West of Ireland. Aquaculture 364-365, 118-123.

Jerlov, N.G., 1976. Marine Optics, Elsevier, New York, 231 pp.

Kordzadze, A.A., Demetrashvili, D.I., 2011. Operational forecast of hydrophysical fields in the Georgian Black Sea coastal zone within the ECOOP. Ocean Science 7, 793-803.

Korotaev, G.K., Oguz, T., Dorofeyev, V.L., Demyshev, S.G., Kubryakov, A.I., Ratner, Y.B., 2011. Development of Black Sea nowcasting and forecasting system. Ocean Science 7, 629-649.

Lehmann, M.K., Fennel, K., He, R., 2009. Statistical validation of a 3-D bio-physical model of the western North Atlantic. Biogeosciences 6, 1961-1974.

Lévy, M., Iovino, D., Resplandy, L., Klein, P., Tréguier, A.-M., Madec, G., Masson, S., Takahashi, K., 2012. Large-scale impacts of submesoscale dynamics on phytoplankton: Local and remote effects. Ocean Modelling 43-44, 77-93.

Lima, I.D., Doney, S.C., 2004. A three-dimensional, multinutrient, and size-structured ecosystem model for the North Atlantic. Global Biogeochemical Cycles 18, GB3019.

Maar, M., Bolding, K., Petersen, J.K., Hansen, J.L.S., Timmermann, K., 2009. Local effects of blue mussels around turbine foundations in an ecosystem model of Nysted off-shore wind farm, Denmark. Journal of Sea Research 62(2-3), 159-174.

Maréchal, D., 2004. A soil-based approach to rainfall-runoff modelling in ungauged catchments for England and Wales. PhD thesis, Cranfield University. 157 pp.

Margolin, L., Smolarkiewicz, P.K., 1999. Antidiffusive velocities for multipass donor cell advection. SIAM Journal on Scientific Computing 20(3), 907-929. 
Mateus, M., 2012. A process-oriented model of pelagic biogeochemistry for marine systems. Part I: Model description. Journal of Marine Systems 94, S78-S89.

Mateus, M., Riflet, G., Chambel, P., Fernandes, L., Fernandes, R., Juliano, M., Campuzano, F., de Pablo, H., Neves, R., 2012. An operational model for the West Iberian coast: products and services. Ocean Science 8, 713-732.

McGrath, T., Nolan, G., McGovern, E., 2011. Chemical characteristics of water masses in the Rockall Trough. Deep Sea Research Part I: Oceanographic Research Papers 61(1), 57-73.

doi:10.1016/j.dsr.2011.11.007.

McMahon, T., Raine, R., Titov, O.V., Boychuk, S., 1995. Some oceanographic features of northeastern Atlantic waters west of Ireland. ICES Journal of Marine Science 52, 221-232.

Moore, T.S., Campbell, J.W., Dowell, M.D., 2009. A class-based approach to characterizing and mapping the uncertainty of the MODIS ocean chlorophyll product. Remote Sensing of Environment 113, 2424-2430.

Nash, J.E., Sutcliffe, J.E., 1970. River flow forecasting through conceptual models. Part I-A discussion of principles. Journal of Hydrology 10(3), 282-290.

Nielsdóttir, M.C., Moore, C.M., Sanders, R., Hinz, D.J., Achterberg, E.P., 2009. Iron limitation of the postbloom phytoplankton communities in the Iceland Basin, Global Biogeochemical Cycles 23, GB3001, doi:10.1029/2008GB003410.

Nolan, G.D., Lyons, K., 2006. Ocean climate variability on the western Irish Shelf, an emerging time series. Proceedings of the ICES Annual Science Conference, Theme Session C, C:28.

Oschlies, A., Koeve, W., Garçon, V., 2000. An eddy-permitting coupled physical-biological model of the North Atlantic: 2. Ecosystem dynamics and comparison with satellite and JGOFS local studies data, Global Biogeochemical Cycles 14, 499-523.

OSPAR, Villars, M., de Vries, I., Bokhorst, M., Ferreira, J., Gellers-Barkmann, S., Kelly-Gerreyn, B., Lancelot, C., Mensguen, A., Moll, A., Pätsch, J., Radach, G., Skogen, M., Soiland, H., Svendsen, E. and Vested, H.J., 1998. Report of the ASMO modelling workshop on eutrophication issues, 5-8 November 1996, The Hague, The Netherlands. Report for Commission Report, Netherlands Institute for Coastal and Marine Management, RIKZ, The Hague, The Netherlands.

OSPAR, 2010. Quality Status Report 2010. OSPAR Commission. London. 176 pp.

Petitgas, P. (Ed.) 2010. Life-cycle spatial patterns of small pelagic fish in the Northeast Atlantic. ICES Cooperative Research Report No. 306. 93 pp.

Raine, R., O’Mahony, J., McMahon, T., Roden, C., 1990. Hydrography and phytoplankton of waters off south-west Ireland. Estuarine, Coastal and Shelf Science 30, 579-592.

Raine, R., McMahon, T., 1998. Physical dynamics on the continental shelf off southwestern Ireland and their influence on coastal phytoplankton blooms. Continental Shelf Research 18, 883-914.

Raine, R., McDermott, G., Silke, J., Lyons, K., Nolan, G., Cusack, C., 2010. A simple short range model for the prediction of harmful algal events in the bays of southwestern Ireland. Journal of Marine Systems 83(3-4), 150-157.

Roden, C.M., Raine, R., 1994. Phytoplankton blooms and a coastal thermocline boundary along the west coast of Ireland. Estuarine, Coastal and Shelf Science 39, 511-526. 
Shchepetkin, A. F., McWilliams, J.C., 2005. The Regional Ocean Modeling System: A split-explicit, free-surface, topography following coordinates ocean model. Ocean Modelling 9, 347-404.

Siddorn, J.R., Allen, J.I., Blackford, J.C., Gilbert, F.J., Holt, J.T., Holt, M.W., Osborne, J.P., Proctor, R., Mills, D.K., 2007. Modelling the hydrodynamics and ecosystem of the North-West European continental shelf for operational oceanography. Journal of Marine Systems 65, 417-429.

Sieracki, M., Verity, P., Stoecker, D., 1993. Plankton community response to sequential silicate and nitrate depletion during the 1989 North Atlantic spring bloom. Deep Sea Research Part II 40, 213-225.

Stanev, E.V., Schulz-Stellenfleth, J., Staneva, J., Grayek, S., Seemann, J., Petersen, W., 2011. Coastal observing and forecasting system for the German Bight - estimates of hydrophysical states. Ocean Science 7, 569-583.

Stow, C.A., Jolliff, J., McGillicuddy Jr., D.J., Doney, S.C., Allen, J.I., Friedrichs, M.A.M., Rose, K.A., Wallhead, P., 2009. Skill assessment for coupled biological/physical models of marine systems. Journal of Marine Systems 76, 4-15.

Sutherland, J., Walstra, D.J.R., Chesher, T.J., vanRijn, L.C., Southgate, H.N., 2004. Evaluation of coastal area modelling systems at an estuary mouth. Coastal Engineering 51, 119-142.

Radach, G., Moll, A., 2006. Review of the three-dimensional ecological modelling related to the North Sea shelf system - part 2: Model validation and data needs. Oceanography and Marine Biology - an Annual Review 44, 1-60.

UCLA, 2003. Application of a Regional Ocean Modeling System (ROMS) to Water and Sediment Quality Issues in the Southern California Bight. Report prepared by the Coastal Center of the UCLA Institute of the Environment in collaboration with the Coastal and Marine Geology Program U.S. Geological Survey. March 2003. 14 pp.

Vichi, M., Pinardi, N., Masina, S., 2007. A generalized model of pelagic biogeochemistry.for the global ocean ecosystem. Part I: Theory. Journal of Marine Systems 64(1-4), 89-109.

Wan, Z., She, J., Maar, M., Jonasson, L., Baasch-Larsen, J., 2012. Assessment of a physicalbiogeochemical coupled model system for operational service in the Baltic Sea. Ocean Science 8, 683701.

Ward, B.A., Friedrichs, M.A.M., Anderson, T.R.A., Oschlies, A., 2010. Parameter optimisation techniques and the problem of underdetermination in marine biogeochemical models. Journal of Marine Systems 81, 34-43.

Zhuang, S.Y., Fu, W.W., She, J., 2011. A pre-operational three Dimensional variational data assimilation system in the North/Baltic Sea. Ocean Science 7, 771-781. 
Table 1. Parameterization of the biogeochemical model

\begin{tabular}{|c|c|c|}
\hline Parameter & Unit & Value* \\
\hline Light attenuation due to seawater & $\mathrm{m}^{-1}$ & 0.04 \\
\hline Light attenuation by chlorophyll & $\mathrm{mg}^{-1} \mathrm{Chl} \mathrm{m}^{-2}$ & 0.02486 \\
\hline Fraction of shortwave radiation that is photosynthetically active & - & 0.43 \\
\hline Eppley temperature-limited growth parameter & - & 1.0 \\
\hline Radiation threshold for nitrification inhibition & $\mathrm{W} \mathrm{m}^{-2}$ & 0.0095 \\
\hline Half-saturation radiation for nitrification inhibition & $\mathrm{W} \mathrm{m} \mathrm{m}^{-2}$ & 0.1 \\
\hline Nitrification rate: oxidation of $\mathrm{NH} 4$ to $\mathrm{NO} 3$ & $\mathrm{~d}^{-1}$ & $0.15(0.05)$ \\
\hline Inverse half-saturation for phytoplankton NO3 uptake & $\mathrm{mmol}^{-1} \mathrm{~N} \mathrm{~m}^{-3}$ & 2.0 \\
\hline Inverse half-saturation for phytoplankton NH4 uptake & $\mathrm{mmol}^{-1} \mathrm{~N} \mathrm{~m}^{-3}$ & 2.0 \\
\hline Zooplankton half-saturation constant (squared) for ingestion & $\mathrm{mmol}^{-1} \mathrm{~N} \mathrm{~m}^{-3}$ & 2.0 \\
\hline Maximum chlorophyll to carbon ratio & $\mathrm{mg} \mathrm{Chl} \mathrm{mg}{ }^{-1} \mathrm{C}$ & 0.0535 \\
\hline Chlorophyll minimum threshold value & $\mathrm{mg} \mathrm{Chl} \mathrm{m}$ & 0.001 \\
\hline Phytoplankton Carbon:Nitrogen ratio & $\mathrm{mol} \mathrm{C} \mathrm{mol}^{-1} \mathrm{~N}$ & 6.625 \\
\hline Phytoplankton, NH4 inhibition parameter & $\mathrm{mmol}^{-1} \mathrm{~N}$ & 1.5 \\
\hline Phytoplankton, initial slope of P-I curve & $\mathrm{mgC} \mathrm{mg}^{-1} \mathrm{Chl} \mathrm{W} \mathrm{m} \mathrm{m}^{-2}$ & 0.025 \\
\hline Phytoplankton minimum threshold value & $\mathrm{mmol} \mathrm{N} \mathrm{m}{ }^{-3}$ & 0.001 \\
\hline Phytoplankton mortality rate & $\mathrm{d}^{-1}$ & 0.15 \\
\hline Zooplankton Nitrogen assimilation efficiency & - & 0.75 \\
\hline Zooplankton Basal metabolism & $d^{-1}$ & 0.1 \\
\hline Zooplankton Carbon:Nitrogen ratio & $\mathrm{mol} \mathrm{C} \mathrm{mol}^{-1} \mathrm{~N}$ & 6.625 \\
\hline Zooplankton specific excretion rate & $\mathrm{d}^{-1}$ & 0.1 \\
\hline Zooplankton maximum growth rate & $d^{-1}$ & $1.3(0.6)$ \\
\hline Zooplankton minimum threshold value & $\mathrm{mmol} \mathrm{N} \mathrm{m}{ }^{-3}$ & 0.001 \\
\hline Zooplankton mortality rate & $\mathrm{d}^{-1}$ & 0.025 \\
\hline Large detritus remineralization rate $\mathrm{N}$-fraction & $\mathrm{d}^{-1}$ & 0.01 \\
\hline Large detritus remineralization rate $\mathrm{C}$-fraction & $d^{-1}$ & 0.01 \\
\hline Coagulation rate of phytoplankton and small detritus & $d^{-1}$ & $0.02(0.005)$ \\
\hline Small detritus remineralization rate $\mathrm{N}$-fraction & $d^{-1}$ & $0.35(0.03)$ \\
\hline Small detritus remineralization rate $\mathrm{C}$-fraction & $\mathrm{d}^{-1}$ & $0.35(0.03)$ \\
\hline Vertical sinking velocity for phytoplankton & $\mathrm{m} \mathrm{d}^{-1}$ & $0.5(0.1)$ \\
\hline Vertical sinking velocity for large detritus & $\mathrm{m} \mathrm{d}^{-1}$ & $10(1.0)$ \\
\hline Vertical sinking velocity for small detritus & $\mathrm{m} \mathrm{d}^{-1}$ & $1.0(0.1)$ \\
\hline
\end{tabular}

*original values used by Fennel et al. (2006) are given in brackets if differ from this application 
Table 2. Statistical measures of model-observation comparison for surface chlorophyll, where $\mathrm{ME}=$ Model Efficiency; $\mathrm{CF}=$ Cost Function; $\mathrm{PB}=$ Percentage of Bias; ARMAE = Adjusted Relative Mean Absolute Error.

\begin{tabular}{|l|c|c|c|c|}
\hline \multicolumn{1}{|c|}{ Region } & ME & CF & PB & ARMAE \\
\hline Bay of Biscay & 0.98 & 0.66 & 20.27 & 0.52 \\
\hline Celtic Sea & 0.98 & 0.63 & 6.90 & 0.38 \\
\hline Irish Shelf & 0.97 & 0.68 & 4.55 & 0.48 \\
\hline Malin Shelf & 0.98 & 0.69 & 13.32 & 0.39 \\
\hline Irish Sea & 0.97 & 0.65 & 82.44 & 0.44 \\
\hline Porcupine Bank & 0.96 & 1.68 & 93.49 & 1.09 \\
\hline Porcupine Bight & 0.94 & 2.40 & 133.94 & 1.43 \\
\hline Rockall Trough & 0.93 & 2.20 & 123.00 & 1.37 \\
\hline Rockall Bank & 0.96 & 1.74 & 86.57 & 1.19 \\
\hline Offshore & 0.95 & 1.70 & 103.54 & 1.23 \\
\hline
\end{tabular}

\begin{tabular}{|l|l|}
\hline & excellent \& very good \\
\hline & good \\
\hline & reasonable \\
\hline poor \& bad \\
\hline
\end{tabular}


Table 3. Comparison of observed and modelled temperature, salinity and nitrate in the regional water masses after entering the Rockall Trough. Mean values are given with standard deviations in the brackets and the ranges observed in different years are provided (see Section 3.4.2 for related surveys). SROCK - southern transect of the RT; NROCK - northern transect of the RT. Observed values are after McGrath et al. (2011). S - salinity (psu), T temperature $\left({ }^{\circ} \mathrm{C}\right)$ and $\mathrm{NO}_{3}$ - nitrates $\left(\mathrm{mmol} \mathrm{m}^{-3}\right)$

\begin{tabular}{|c|c|c|c|c|c|c|c|c|}
\hline \multirow{2}{*}{ Watermass } & \multirow{2}{*}{ Section } & \multirow{2}{*}{ Depth } & \multicolumn{3}{|c|}{ Observations } & \multicolumn{3}{|c|}{ Model } \\
\hline & & & $\mathrm{S}$ & $\mathrm{T}$ & $\mathrm{NO}_{3}$ & $\mathrm{~S}$ & $\mathrm{~T}$ & $\mathrm{NO}_{3}$ \\
\hline \multirow{2}{*}{$\begin{array}{l}\text { SW (surface } \\
\text { waters) }\end{array}$} & SROCK & $0-300$ & $35.41-35.53(0.01-0.1)$ & $10.52-11.35(0.1-0.3)$ & 7.3-11.7 (0.4-1) & $35.51(0.03)$ & $10.71(0.31)$ & $10.95(0.2)$ \\
\hline & NROCK & $0-300$ & $35.4-35.47(0.02-0.1)$ & $10.39-10.96(0.2-0.3)$ & $8.08-11.5(0.3-0.8)$ & $35.49(0.02)$ & $10.43(0.2)$ & $11.4(0.4)$ \\
\hline \multirow[t]{2}{*}{ ENAW* } & SROCK & $0-700$ & $34.98-35.23$ & $6.37-11.84$ & $6.4-21.7$ & $35.5(0.05)$ & $10.58(0.49)$ & $11.5(1.07)$ \\
\hline & NROCK & $0-700$ & $35.19-35.55$ & $7.58-11.27$ & $7.62-19.1$ & $35.48(0.03)$ & $10.33(0.31)$ & $11.5(0.5)$ \\
\hline SAIW & SROCK & $700-1000$ & $35.08-35.12(0.04-0.1)$ & $5.73-6.05(0.5-0.8)$ & $17.7-19.5(0.1-0.9)$ & $35.29(0.06)$ & $8.0(0.78)$ & $16.0(0.33)$ \\
\hline MW & SROCK & $700-800$ & $35.32-35.38(0.03-0.1)$ & $9.12-9.28(0.2-0.5)$ & $17.3-18.8(0.2-1.1)$ & $35.61(0.03)$ & $10.34(0.25)$ & $13.16(0.5)$ \\
\hline WTOW* & NROCK & $800-1100$ & $35.03-35.35$ & $5.02-9.48$ & $17.8-18.3$ & $35.26(0.05)$ & $7.71(0.69)$ & $15.8(0.5)$ \\
\hline \multirow[t]{2}{*}{ LSW } & SROCK & $1500-2000$ & $34.91-34.92(0.01-0.02)$ & $3.65-3.7(0.2-0.3)$ & $17.8-18.5(0.2-1)$ & $34.92(0.01)$ & $3.53(0.25)$ & $18.1(0.4)$ \\
\hline & NROCK & $1500-2000$ & $34.93-34.94(0.01-0.02)$ & $3.78-3.92(0.3)$ & $17.7-18.3(0.2-0.4)$ & $34.96(0.03)$ & $4.0(0.39)$ & $17.6(0.5)$ \\
\hline \multirow{2}{*}{$\begin{array}{l}\text { NEADW } \\
\text { upper }\end{array}$} & SROCK & $2500-2600$ & $34.93-34.95(0)$ & $3-3.12(0.1)$ & $18.5-22.3(0.6)$ & $34.94(0)$ & $3.0(0.05)$ & $20.4(0.4)$ \\
\hline & NROCK & $2500-2600$ & $34.92-34.94(0)$ & $2.96-3.04(0.1)$ & $18.3-22.1$ & $34.94(0)$ & $3.09(0.03)$ & $20.1(0.4)$ \\
\hline \multirow{2}{*}{$\begin{array}{l}\text { NEADW } \\
\text { lower }\end{array}$} & SROCK & $2900-3000$ & $34.92-34.94(0.01)$ & $2.56-2.76(0.1-0.2)$ & $21.4-21.6(0.04-0.8)$ & $34.93(0)$ & $2.73(0.07)$ & $21.7(0.8)$ \\
\hline & NROCK & $>2800$ & $34.92-34.94(0)$ & $2.68-2.77(0.04-0.1)$ & $20.3-21.4(0.2-0.5)$ & $34.94(0)$ & $2.97(0.06)$ & $21.5(0.5)$ \\
\hline AABW & SROCK & $>2990$ & $34.91-34.93(0.01)$ & $2.51-2.6(0.03-0.1)$ & $22.2-23.3(0.1-0.2)$ & $34.93(0)$ & $2.57(0.11)$ & $22.2(0.77)$ \\
\hline
\end{tabular}

$*$ The minimum and maximum values observed for this water masses are provided 


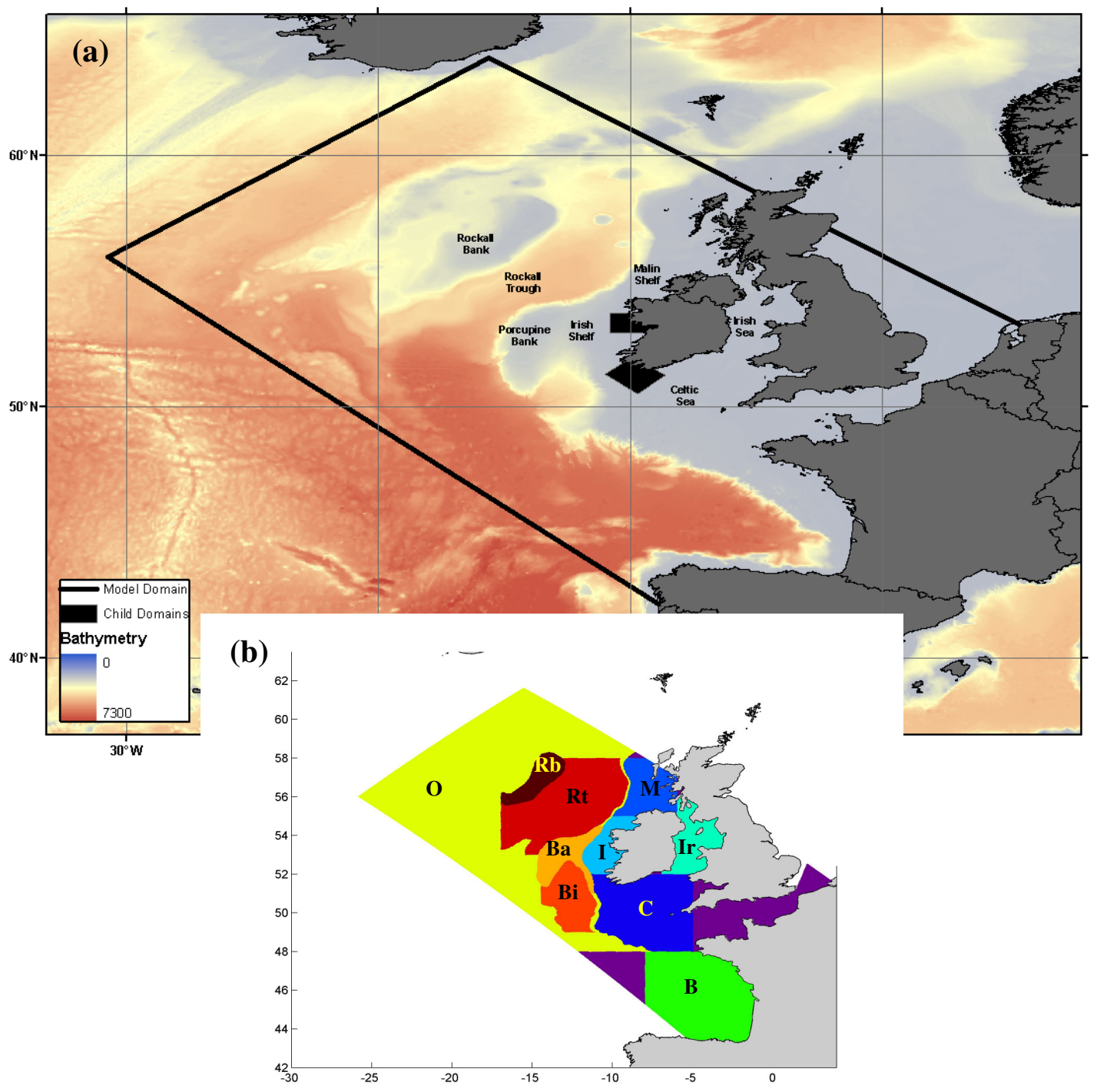

Figure 1. (a) Extents of the NEA_ROMS4k model ('Model Domain'). Also shown are two high resolution nested coastal models ('Child Domains') run operationally by the Marine Institute; (b) definition of sub-regions for model skill assessment: B - bay of Biscay, C - Celtic Sea, I - Irish Shelf, M - Malin Shelf, Ir - Irish Sea, Bi - Porcupine Seabight, Ba - Porcupine Bank, Rt - Rockall Trough, $\mathrm{Rb}$ - Rockall Bank, $\mathrm{O}$ - offshore waters (include $\mathrm{Bi}, \mathrm{Ba}$, Rt and $\mathrm{Rb}$ ). Offshore waters $(\mathrm{O})$ are deeper than $200 \mathrm{~m}$ and north of $48^{\circ} \mathrm{N}$. 

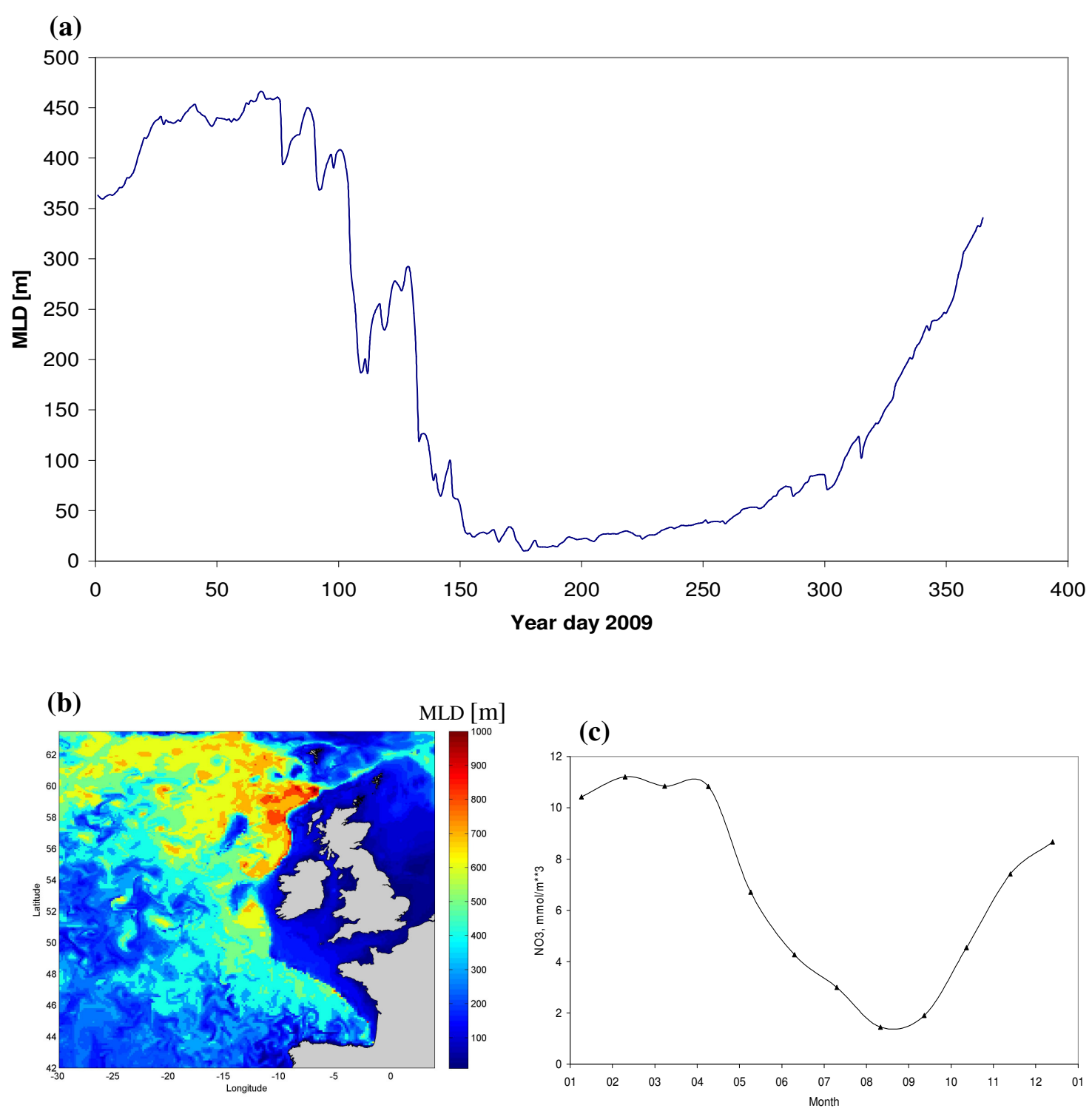

Figure 2. (a) Annual pattern of MLD averaged over $50-60^{\circ} \mathrm{N}$ and $8-24^{\circ} \mathrm{W}$, (b) spatial distribution of MLD on the $1^{\text {st }}$ of March 2009 in NE Atlantic obtained from the Mercator model (the criterion $\Delta \mathrm{T}=$ $0.2^{\circ} \mathrm{C}$ was used to compute MLD) and (c) monthly nitrate climatology over $50-60^{\circ} \mathrm{N}$ and $8-24^{\circ} \mathrm{W}$ from WOA09. 


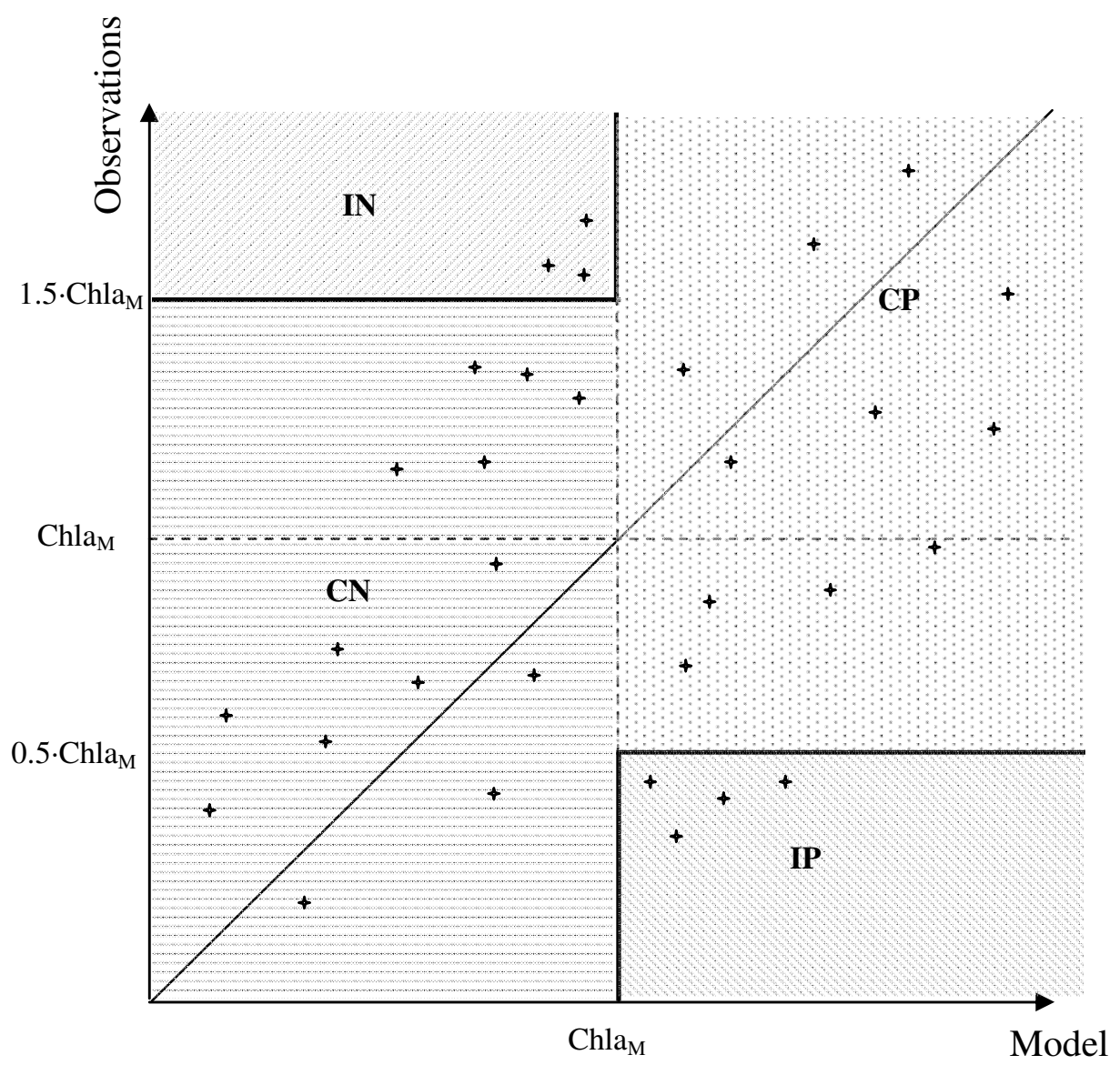

Figure 3. Schematic diagram of the binary discrimination test, where $\mathrm{CP}=$ correctly positive; $\mathrm{CN}=$ correctly negative; IP = incorrectly positive; IN = incorrectly negative. 

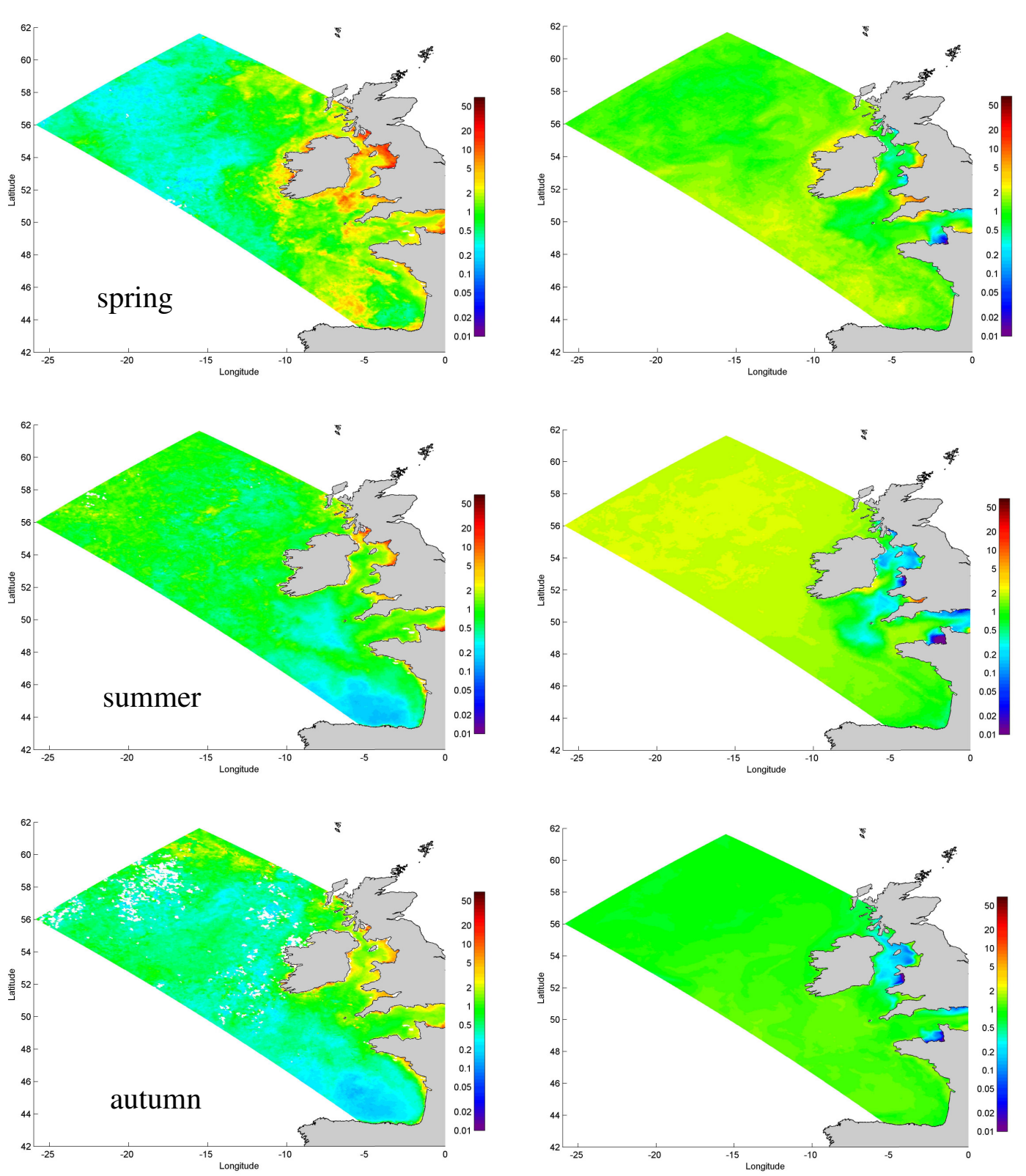

Figure 4. Comparison of spring (March-May), summer (June-August) and autumn (September November) chlorophyll concentrations from MODIS (left column) sensor and the model (right column). 

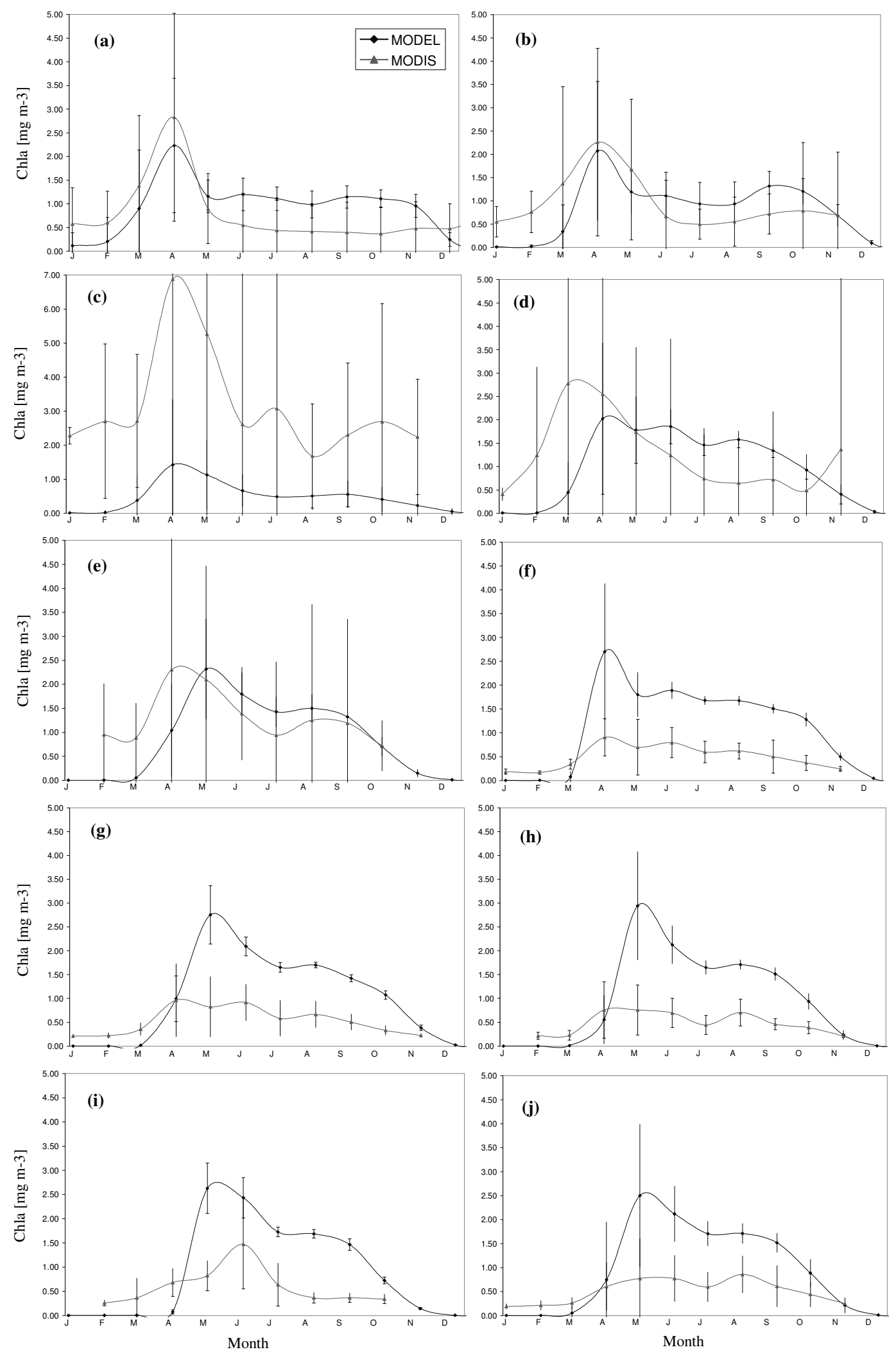

Figure 5. Monthly chlorophyll (solid line) with one standard deviation (error bar) from the model and MODIS averaged over individual subregions: (a) Bay of Biscay, (b) Celtic Sea, (c) Irish Sea, (d) Irish Shelf, (e) Malin Shelf, (f) Porcupine Seabight, (g) Porcupine Bank, (h) Rockall Trough, (i) Rockall Bank and (j) offshore waters. 

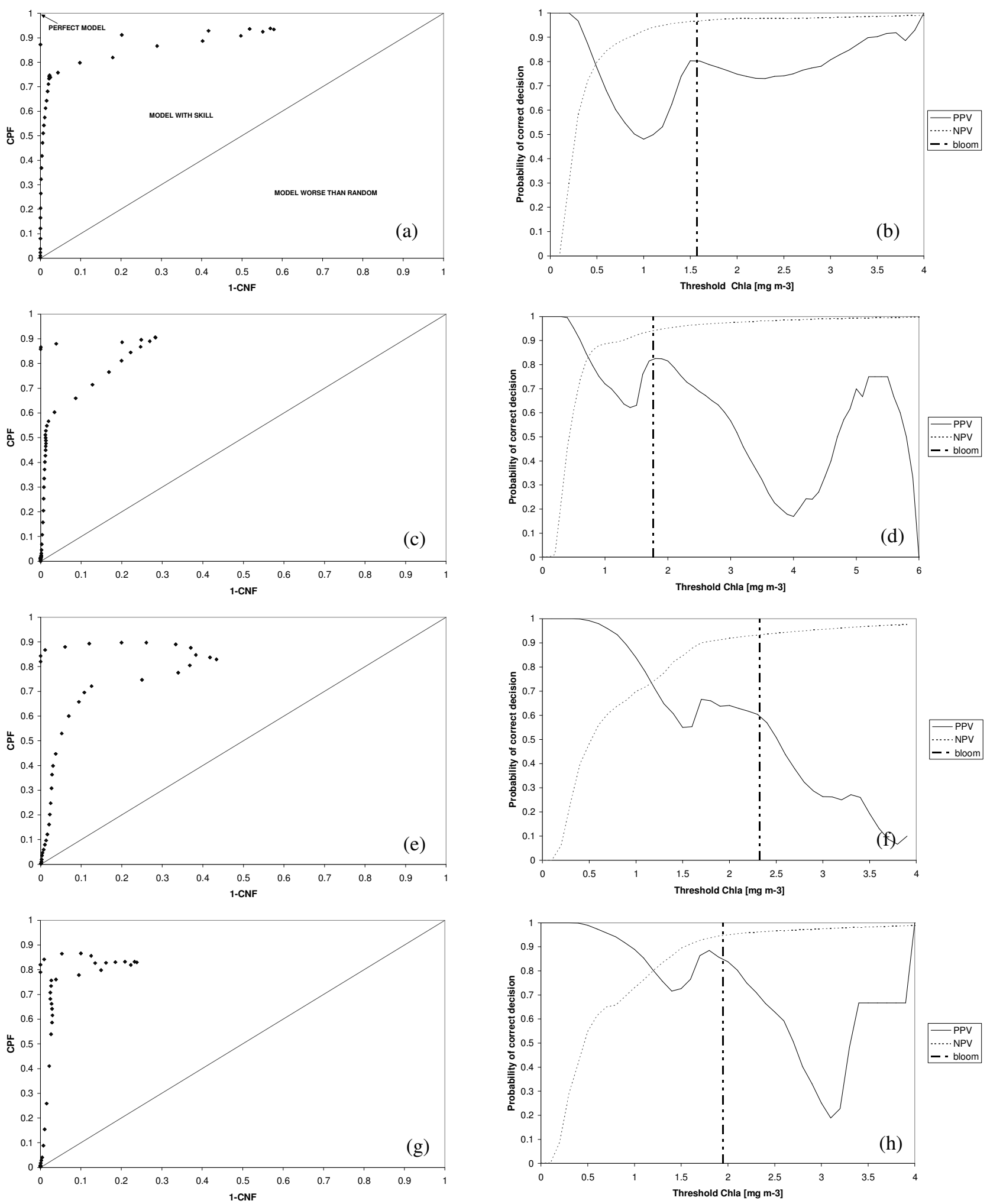

Figure 6. Binary discrimination test plots of model performance for chlorophyll in (a-b) Bay of Biscay, (c-d) Celtic Sea, (e-f) Irish Shelf and (g-h) Malin Shelf. Left panel - the binary discrimination skill assessment curves; right panel - the probabilities that a positive or a negative decision is correct at various discrimination thresholds. $\mathrm{CPF}=$ close to the perfect model; $\mathrm{CNF}=$ correct negative fraction; $\mathrm{PPV}=$ positive predictive value; $\mathrm{NPV}=$ negative predictive value. The perfect model is when $\mathrm{CPF}=1$ and $1-\mathrm{CNF}=0$. A high PPV or NPV value indicates that the decision can be trusted. 

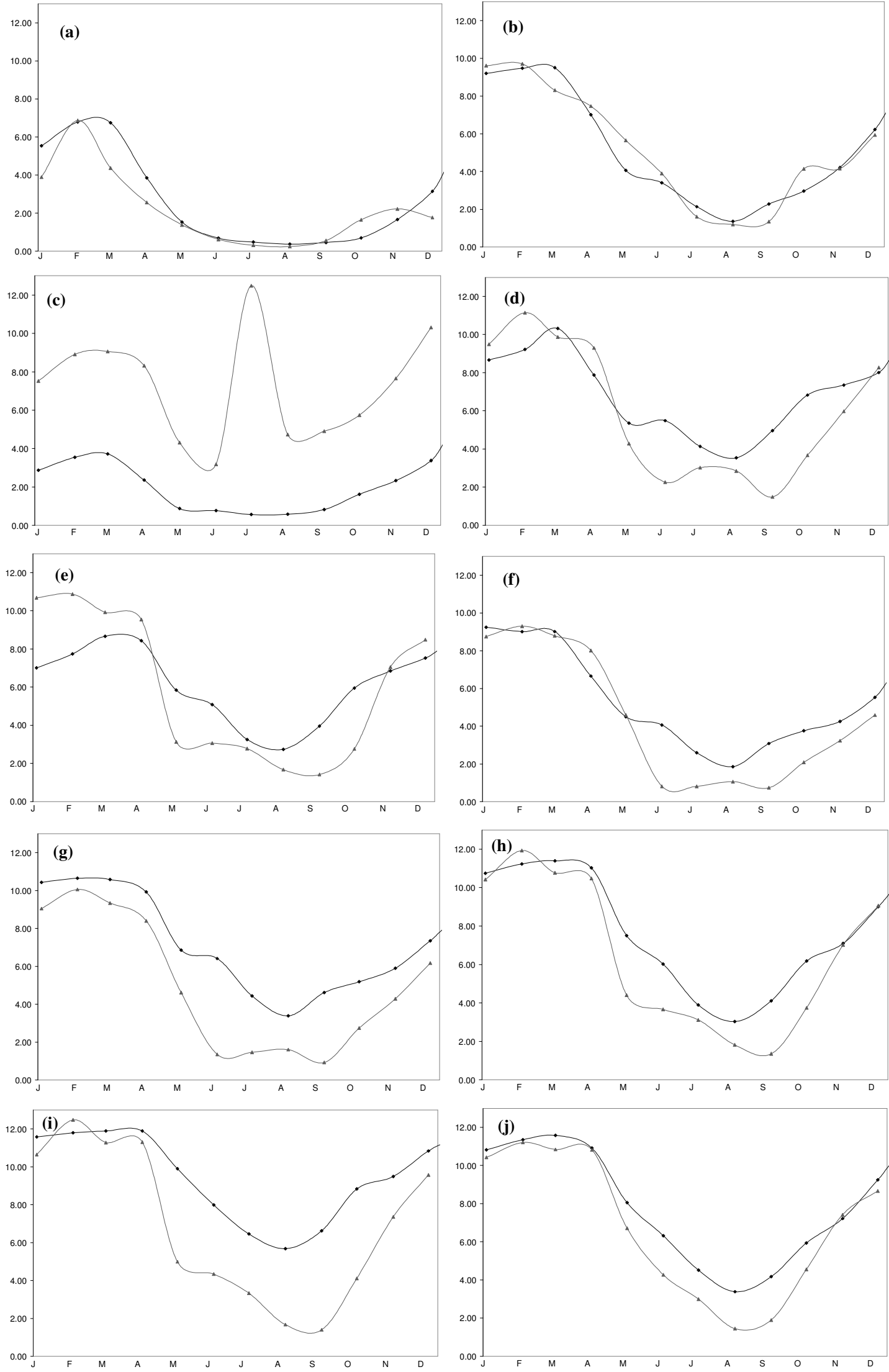

Figure 7. Monthly nitrates from the model (dark line) and WOA09 (light line) averaged over individual subregions: (a) Bay of Biscay, (b) Celtic Sea, (c) Irish Sea, (d) Irish Shelf, (e) Malin Shelf, (f) Porcupine Seabight, (g) Porcupine Bank, (h) Rockall Trough, (i) Rockall Bank and (j) offshore waters. 


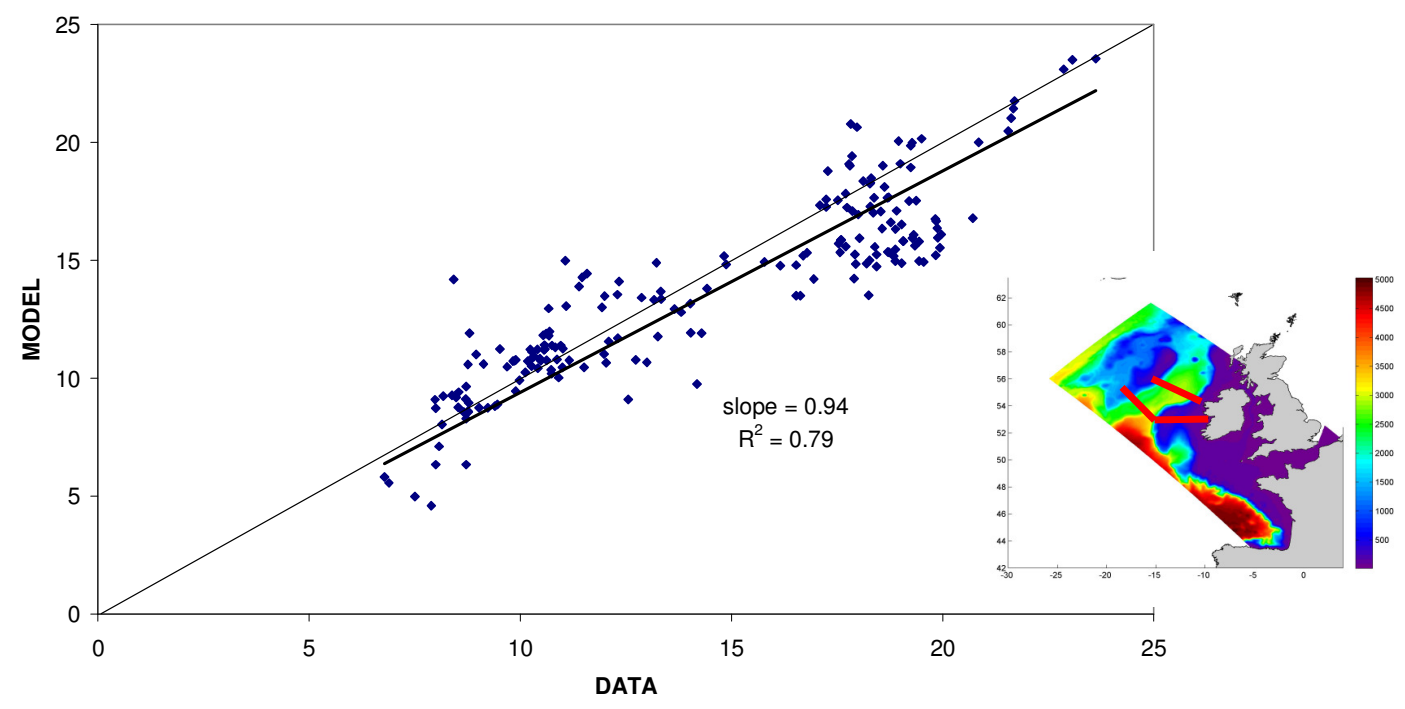

Figure 8. Regression plot of measured and modelled nitrates in January 2011 along transects to the west of Ireland. 

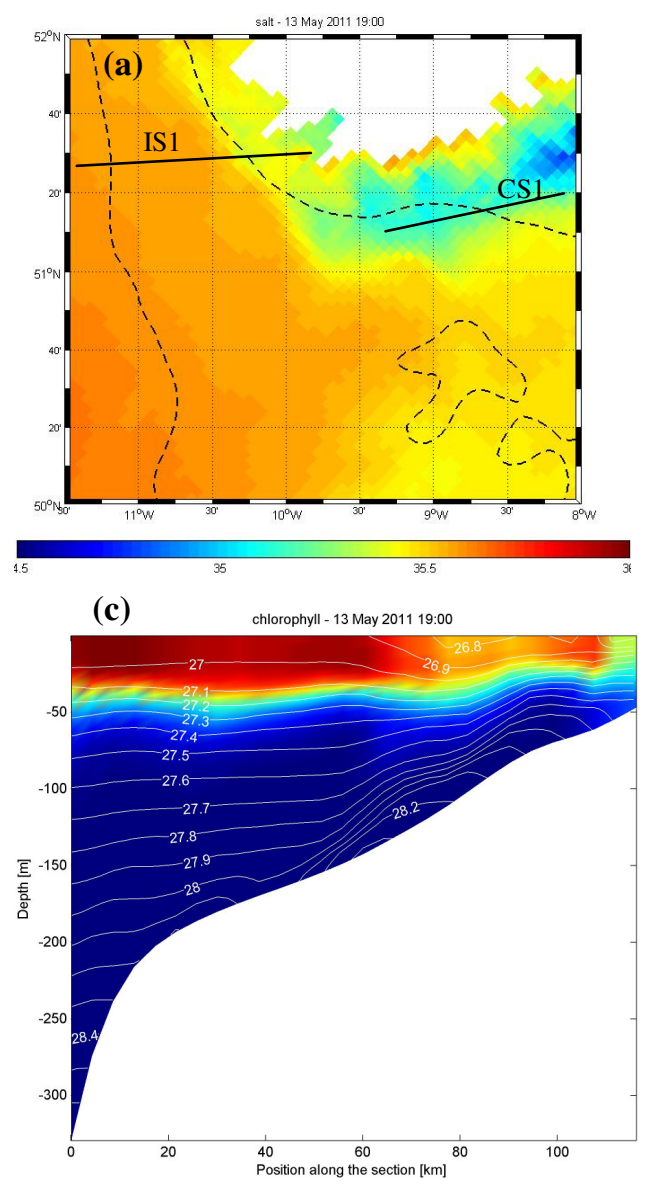

(e)

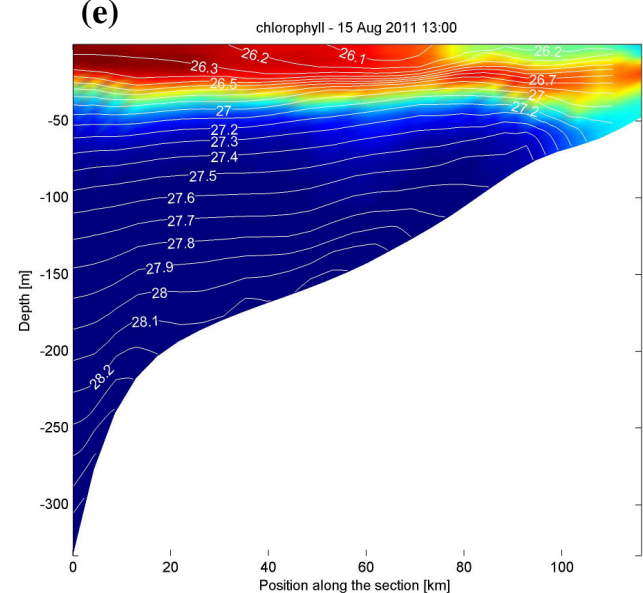

(g)

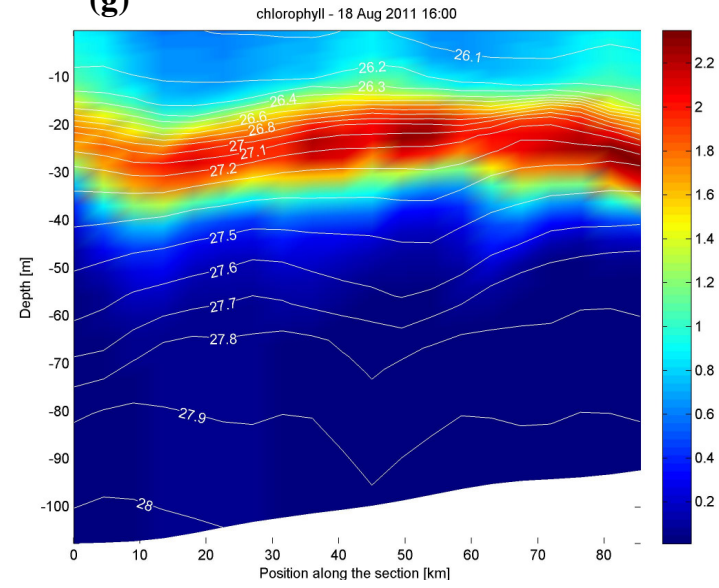

(b)

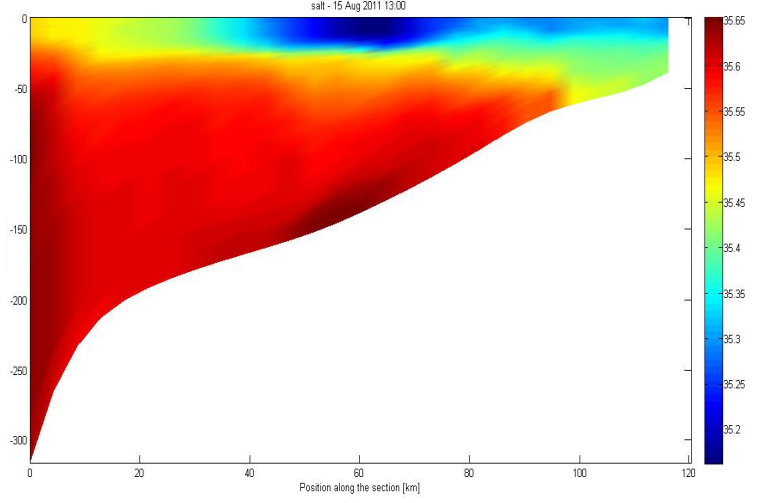

(d)
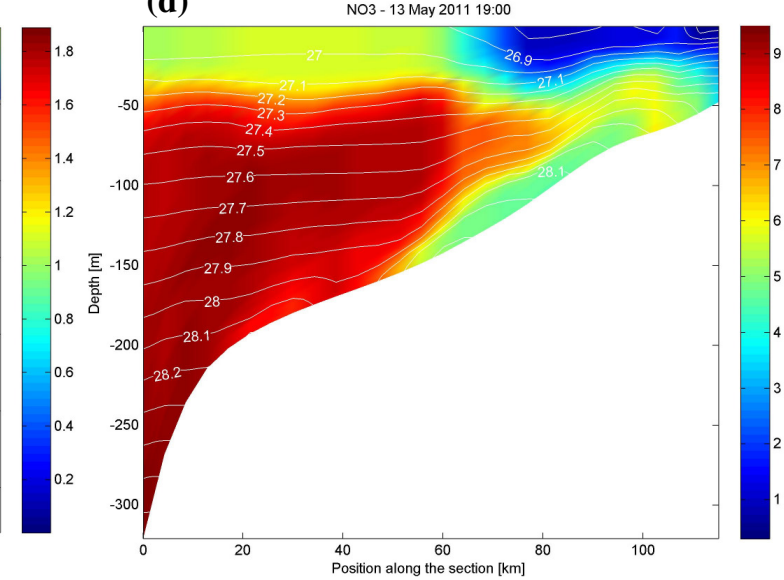

(f)

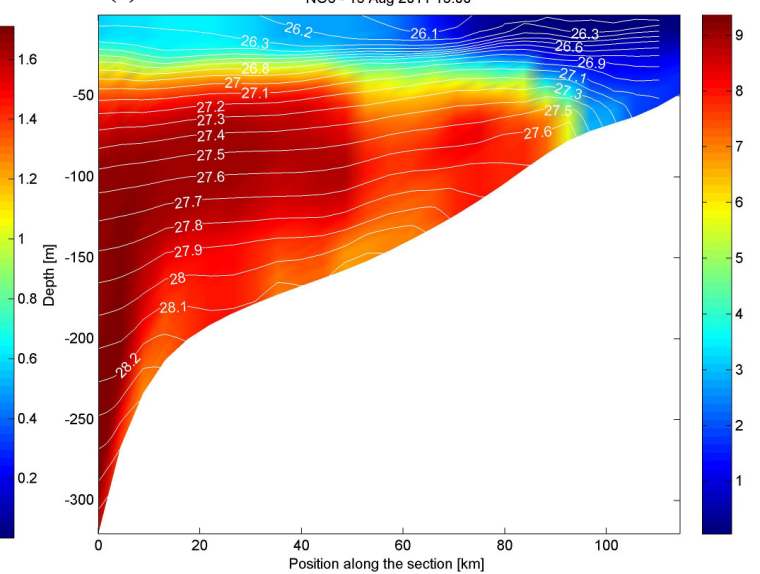

(h)

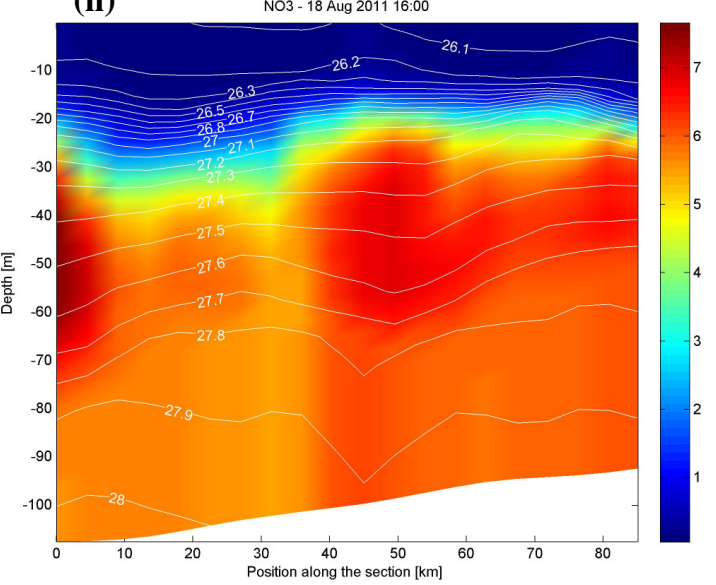

Figure 9. Location of transects off the southwestern coast of Ireland showing also the surface signature of the ISF expressed by salinity gradients (a), isohalines along transect IS 1 showing the ISF in mid-August 2011 in the model (b), vertical sections through modelled Chla $\left[\mathrm{mg} \mathrm{m}^{-3}\right]$ and $\mathrm{NO}_{3}\left[\mathrm{mmol} \mathrm{N} \mathrm{m}^{-3}\right]$ along transect IS1 in mid-May (c-d) and mid-August (e-f) and along transect CS1 in mid-August (g-h). Also shown are isopycnals (sigma-t). 

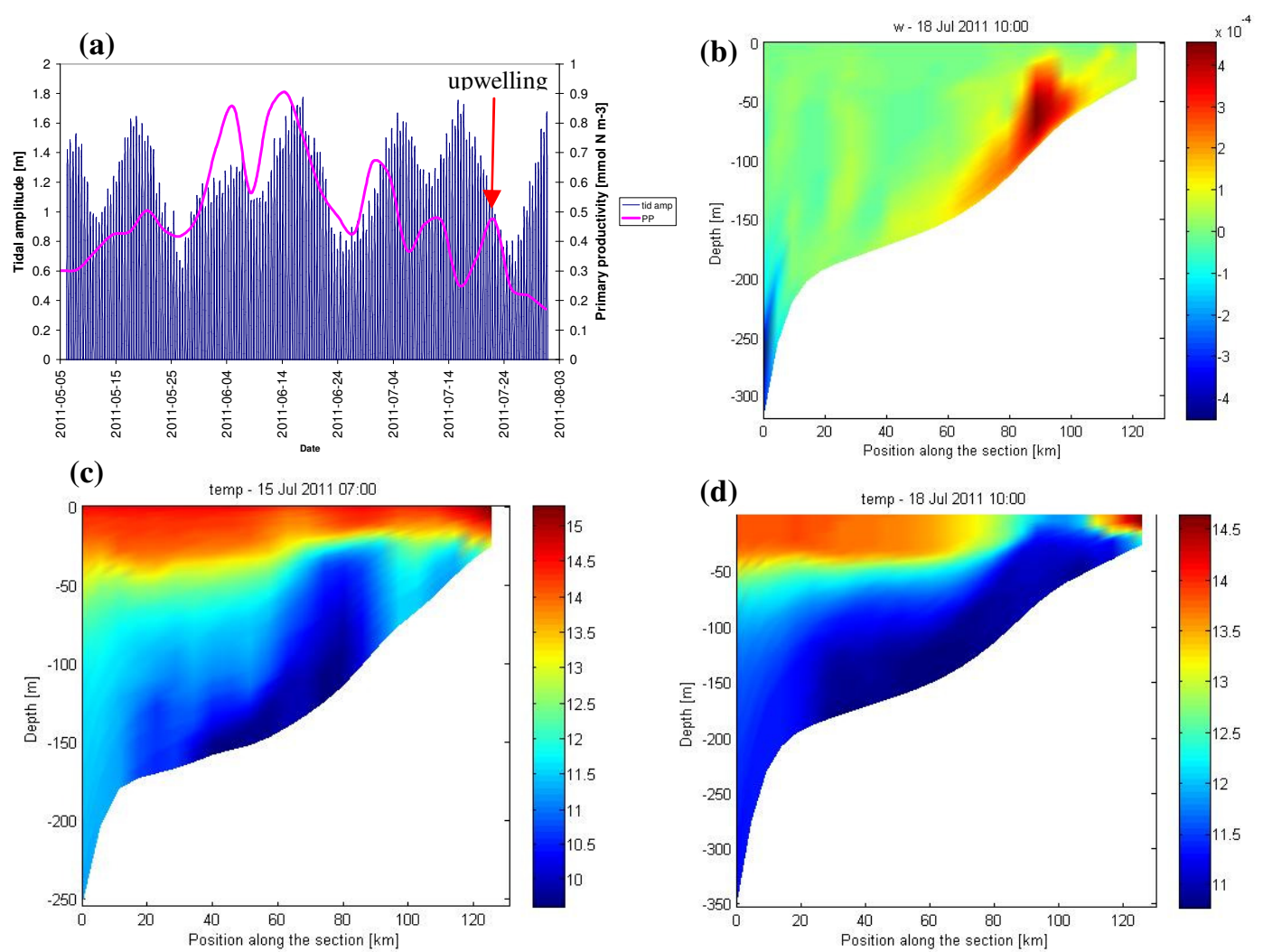

(e)
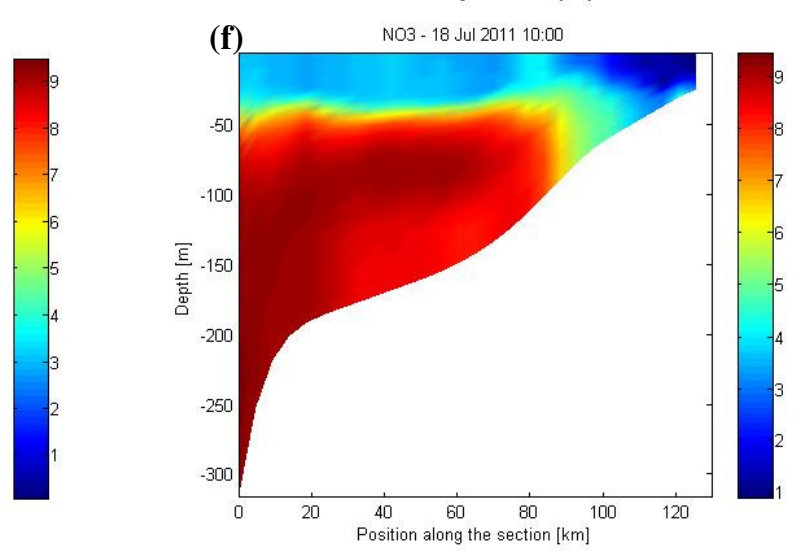

Figure 10. Modelled (a) tidal amplitudes and primary productivity in the surface layers in coastal waters around Bantry Bay (southwest Ireland) between May-July 2011; (b) section through a 3-day averaged vertical velocities on 17-19 July 2011 along transect IS1 showing strong upwelling; (c, d) sections through water temperatures prior to and post upwelling, respectively; $(\mathrm{e}, \mathrm{f})$ sections through nitrates prior to and post upwelling, respectively. 
(a)

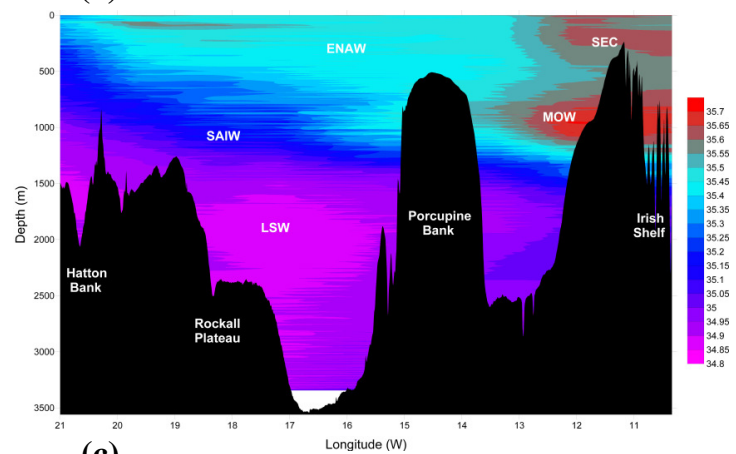

(c)

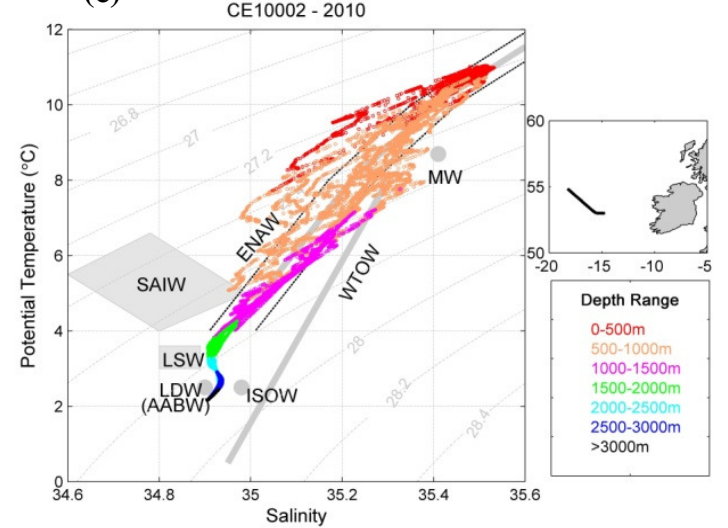

(e)
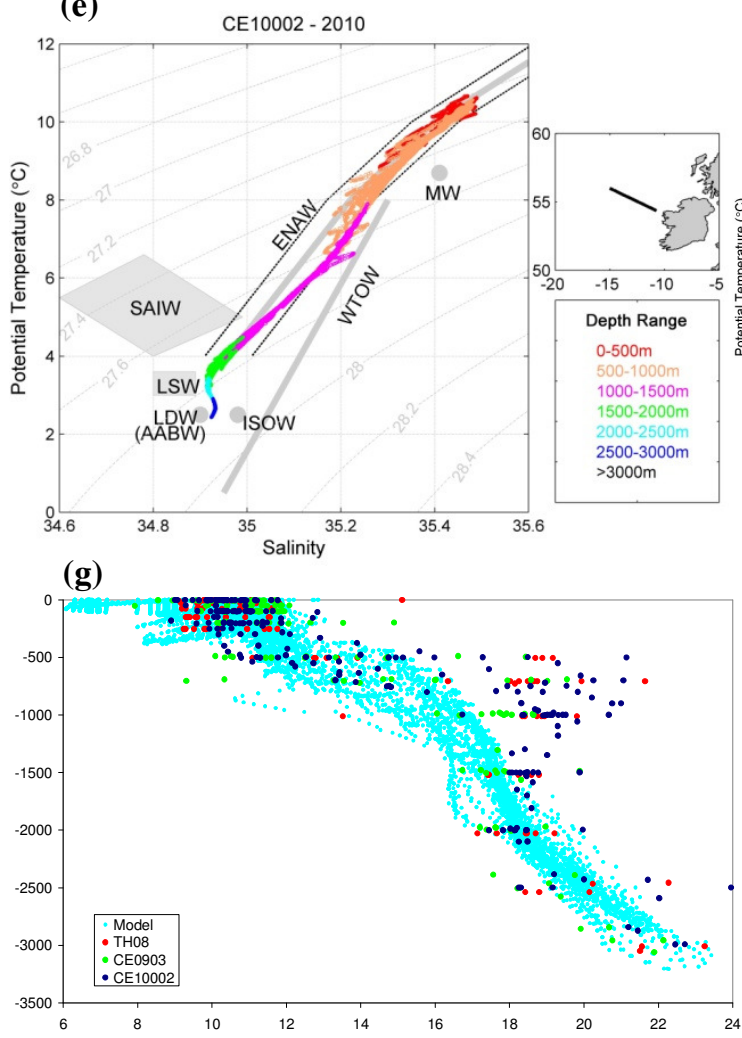

(b)

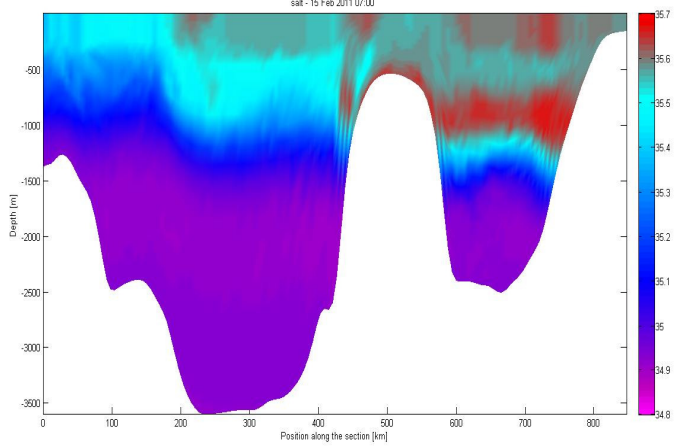

(d)
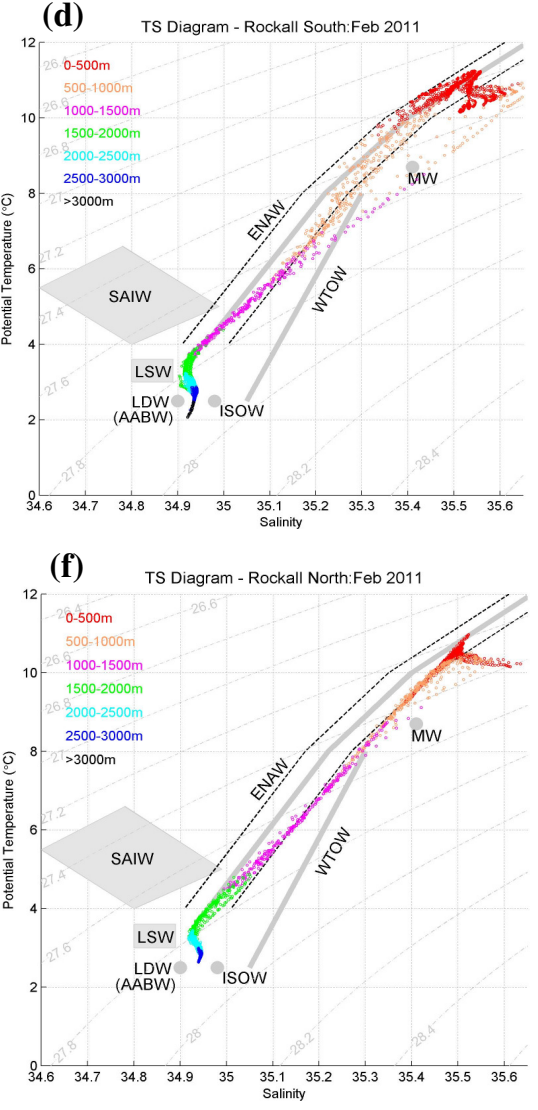

Figure 11. Comparison of observed and modelled physico-chemical characteristics of the Rockall Trough (RT) water masses: (a) cross section of salinity across the southern RT taken from a 2010 National Seabed Survey, (b) cross section of modelled salinity along the same transect, (c) $\theta$-S plot using CTD CE10002 February 2010 cruise data of the southern RT transect and (e) northern RT transect, (d) corresponding $\theta$-S plot obtained from the model for the southern RT and (f) northern RT transects, (g) observed and modelled vertical profiles of $\mathrm{NO}_{3}$ across both transects. Where ENAW= Eastern North Atlantic Water; SAIW = Subarctic Intermediate Water; MW = Mediterranean Water; WTOW = Wyville-Thomson Overflow Water; LSW = Labrador Sea Water; NEADW = Northeast Atlantic Deep Water; AABW = Antarctic Bottom Water. 